Summary: Although several major progresses have been introduced in the field of bone regenerative medicine during the years, current therapies, such as bone grafts, still have many limitations. Moreover, and in spite of the fact that material science technology has resulted in clear improvements in the field of bone substitution medicine, no adequate bone substitute has been developed and hence large bone defects/injuries still represent a major challenge for orthopaedic and reconstructive surgeons. It is in this context that TE has been emerging as a valid approach to the current therapies for bone regeneration/substitution. In contrast to classic biomaterial approach, TE is based on the understanding of tissue formation and regeneration, and aims to induce new functional tissues, rather than just to implant new spare parts. The present review pretends to give an exhaustive overview on all components needed for making bone tissue engineering a successful therapy. It begins by giving the reader a brief background on bone biology, followed by an exhaustive description of all the relevant components on bone TE, going from materials to scaffolds and from cells to tissue engineering strategies, that will lead to "engineered" bone.

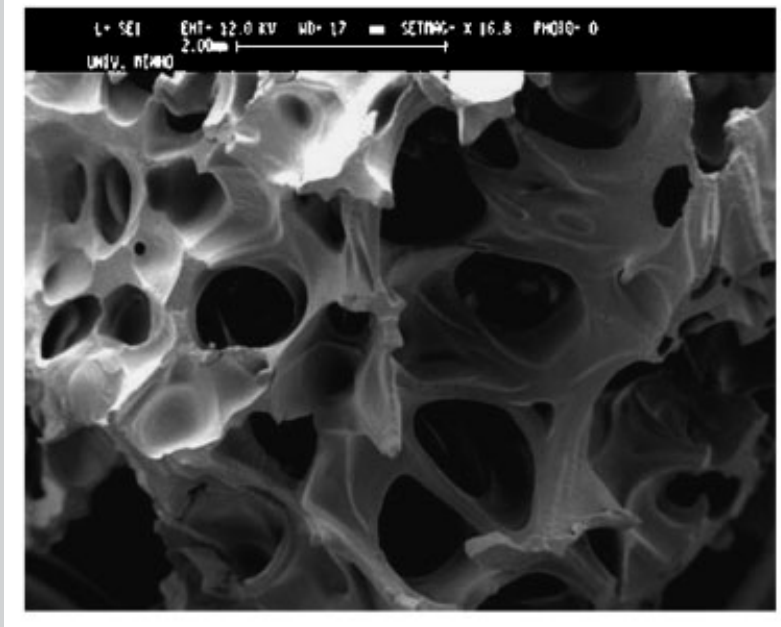

Scaffolds processed by using a methodology based on extrusion with blowing agents.

\title{
Bone Tissue Engineering: State of the Art and Future Trends
}

\author{
António J. Salgado, ${ }^{1,2}$ Olga P. Coutinho, ${ }^{1,3}$ Rui L. Reis ${ }^{1,2}$ \\ ${ }^{1}$ 3B's Research Group, Biomaterials, Biodegradables and Biomimetics, University of Minho, Campus de Gualtar, \\ 4710-057 Braga, Portugal \\ Fax: +35 1253604492; E-mail: asalgado@dep.uminho.pt \\ ${ }^{2}$ Department of Polymer Engineering, University of Minho, Campus de Azurém, 4800-058, Guimarães, Portugal \\ ${ }^{3}$ Department of Biology, University of Minho, Campus de Gualtar, 4710-057 Braga, Portugal
}

Received: February 17, 2004; Revised: May 1, 2004; Accepted: May 18, 2004; DOI: 10.1002/mabi.200400026

Keywords: bioengineering; biomaterials; bone; scaffolds; tissue engineering

\section{Introduction}

Bone is a dynamic, highly vascularised tissue with a unique capacity to heal and remodel without leaving a scar. ${ }^{[1]}$ These properties, together with its capacity to rapidly mobilize mineral stores on metabolic demand, make it the ultimate smart material. Its main role is to provide structural support for the body. Furthermore the skeleton also serves as a mineral reservoir, supports muscular contraction resulting in motion, withstands load bearing and protects internal organs. ${ }^{[1,2]}$ Hence, it is logical to say that major alterations in its structure due to injury or disease can dramatically alter one's body equilibrium and quality of life.

Although major progresses were done in the field of bone regenerative medicine during the years, current therapies, such as bone grafts, still have several limitations, as it will be later discussed in the present review. Moreover, and despite of the fact that materials science technology has resulted in clear improvements in the field of bone substitution medicine, no adequate bone substitute has been developed. Thus, most of the severe injuries related to bone are still unrecoverable or not adequately treated.

It is in this context that an emerging field of science called Tissue Engineering (TE) has been gaining notoriety in the last 10 years.

The present review intends to provide the reader an overview of the current state of the art in bone tissue engineering, its limitations and hopes as well as the future research trends for this exciting field of science. 


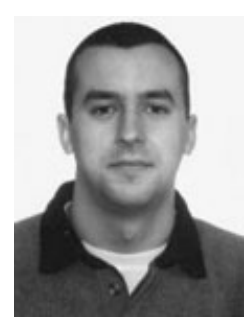

António J. Salgado was born in Braga (Portugal) in 1978. In 2000 he obtained his BSc in Applied Biology from the University of Minho (Braga, Portugal), with a final research work conducted at the Centre for Neuroscience and Cell Biology of Coimbra. Since January 2001, he has been a PhD student/ researcher at 3B's Research Group - Biomaterials, Biodegradables, Biomimetics, (Department of Polymer Engineering, University of Minho) under the supervision of Prof. Rui L. Reis. The objective of his research has been the development of novel tissue engineering strategies for bone and osteochondral replacement, using novel starch based scaffolds. This research work has also involved other institutional partners, namely the Department of Biology of University of Minho (local supervision: Dr. Olga P. Coutinho), National University of Singapore (local supervision: Dr. Dietmar W. Hutmacher) and University of Toronto (local supervision: Prof. John E. Davies). Other research interests focus on basic bone and adult stem cell biology, biodegradable biomaterials, novel processing methodologies for the development of porous scaffolds and animal models for bone tissue engineering. He is currently author of 7 papers in international refereed journals, 7 book chapters and 26 communications in conferences. His work was recently selected for the front cover of one of the issues of the Tissue Engineering journal.

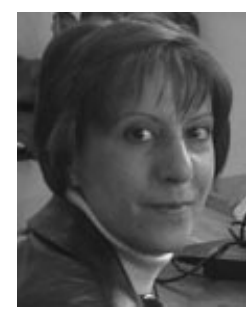

Olga P. Coutinho is graduated in Biology and received the Ph.D. in Cellular Biology from the University of Coimbra, Portugal. She currently has a position as an Assistant Professor at the Department of Biology, University of Minho, Portugal. As a lecturer, she is responsible for Biochemistry, Neurobiology and Pharmacology classes. The starting field of her research career was in the Neurochemistry area, namely on calcium regulating mechanisms of neurotransmission. After a six years experience in Pharmaceutical Industry, as Clinical Research Associate, she returned to the academic career at the University of Minho, and integrated the 3B's Research group, a Research Center of Excellence, from the Portuguese Scientific Foundation (FCT). Her areas of research interest are now in biochemical approaches for tissue engineering purposes as well as on the antioxidant potential of new compounds for diseases involving oxidative stress. The output of this research includes several publications in the mentioned areas, as well as the supervision of Ph.D. and Master students.

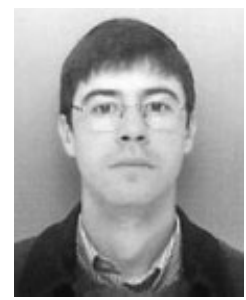

Rui L. Reis was born in 1967 in Porto, Portugal, where he still lives. At the present he is an Associate Professor at the Department of Polymer Engineering of the University of Minho, in the Northern part of Portugal, where he is also Director of the 3B's Research Group - Biomaterials, Biodegradables and Biomimetics. Previously, he has been a Lecturer at the Department of Metallurgical and Materials Science Engineering, University of Porto. He is Director of R\&D of the Cork Industries Holding of the AMORIM Group, one of the main economical groups with world-wide operations based in Portugal, where he directs a team fully devoted to the development of new cork based products. Dr. Rui L. Reis education background includes: (i) a five years graduation in Metallurgical Engineering, University of Porto, (ii) a two years Master degree in Materials Science and Engineering - Biomaterials - obtained in a joint program of the six major technical Universities in Portugal and (iii) a PhD degree in Polymer Engineering - Biomaterials, University of Minho, Portugal, that was prepared in co-operation with Brunel University, UK. Rui L. Reis has been involved in biomaterials research since 1990. His main area of research is the development of biomaterials from starch and other natural origin polymers (casein, soy, chitin, chitosan, algae) that his group originally proposed for a range of biomedical applications, including bone replacement and fixation, drug delivery carriers, partially degradable bone cements and tissue engineering scaffolding. He has also been involved in several EU funded projects, and he is currently the coordinator of the only Network of Excellence (NoE) on Tissue Engineering under the FP6. Rui L. Reis is an author of more than 100 papers in scientific journals, 1 international patent, 3 books, 5 journal special issues, around 80 book chapters in books of international circulation and in international encyclopaedias, and more than 360 communications in conferences. Around 330 of those communications were presented in international meetings, including around 40 plenary or invited talks. He presented also 35 invited lectures in other universities or research institutes. As a result of his academic activities Rui L. Reis has been awarded several prizes. The two last ones were: (i) the ESAFORM 2001 Scientific Prize for his work on processing of starch based biomaterials and (ii) the Jean LeRay Award 2002 by the European Society for Biomaterials for its outstanding contributions to the biomaterials field as a young scientist. 


\section{Brief Insights in Bone Biology}

Bone tissue in the adult skeleton is arranged in two architectural forms: ${ }^{[3-5]}$ trabecular, also called cancelous or spongy bone (around $20 \%$ of the total skeleton), and cortical or compact bone (around $80 \%$ of the total skeleton).

The proportions of these two architectural forms differ at various locations in the skeleton. Cortical bone is almost solid, being only $10 \%$ porous, ${ }^{[3]}$ and can be divided into different subgroups: ${ }^{[3,5]}$ long bones (femur and tibia), short bones (wrist and ankle), and flat bones (skull vault and irregular bones). On the other end, trabecular bone presents a higher porosity, 50-90\%, making its modulus and ultimate compressive strength around 20 times inferior than that of cortical bone. ${ }^{[3,6]}$ Trabecular bone is arranged in a sponge-like form, with a honeycomb of branching bars, plates and rods of various sizes called trabeculae. It is commonly found in methaphysis of long bones, covered by cortical bone, and in the vertebral bodies. ${ }^{[3-5]}$

The elaboration, maintenance and resorption of this remarkable tissue results from the interaction of three cell types: ${ }^{[7-11]}$ osteoblasts, osteocytes and osteoclasts. All of them have defined tasks and are thus essential for the maintenance of a healthy bone tissue. Further details on the characteristics and functions of these cells can be found in Table 1 .

As it was previously referred, bone is involved in a serious of processes which are found to be essential for the human body. Most of the outstanding properties of bone are related to its matrix constitution. Bone matrix has two components: a mineral part constituted by hydroxylapatite which contributes with $65-70 \%$ to the matrix and an organic part, composed of glycoproteins, proteoglycans, sialoproteins, bone "gla" proteins, that comprises the remaining $25-30 \%$ of the total matrix. ${ }^{[1]}$ Because of this, and from a materials science perspective, bone can be considered as a truly composite material. Several different proteins with different functions constitute the organic phase of the bone matrix. For a simple presentation and better understanding by the reader the components of the bone organic phase are summarized in Table 2.

Other important aspects related with bone biology are those that deal with the processes of bone formation, differences between woven and lamellar bone and matrix mineralization. However, and because it is not the objective of the present review to make a detailed description of bone biology these will not be focused here. For this purpose we advice the reader to read the following reports, ${ }^{[23-29]}$ which have thoughtful discussions on the referred subjects.

\section{Clinical Needs in the Bone Replacement and Regeneration Field}

There are roughly 1 million cases of skeletal defects a year that require bone-graft procedures to achieve union. ${ }^{[30]}$ Socioeconomic consequences in treating these patients with bone fractures is a major concern for both USA and EU, which will increase in the next years due the ageing of their population. Current treatments are based on autologous bone grafts, autogenous bone grafts or as an alternative to these, metals and ceramics. ${ }^{[30-34]}$

Autologous bone graft, that is, bone taken from another part of the patient's own body, has been the gold standard of bone replacement for many years because it provides osteogenic cells as well as essential osteoinductive factors needed for bone healing and regeneration. ${ }^{[33,35]}$ It is commonly taken in the form of trabecular bone from the patient's iliac crest, but cortical bone can be used as well. ${ }^{[33,36]}$ However, and although it presents relatively good percentages of success, the spectrum of cases in which it can be used is restricted, mainly due to the limited amount of the autograft that can be obtained and due to donor site morbidity. ${ }^{[30-34]}$

Allograft, bone taken from somebody else's body, could be an alternative. However, the rate of graft incorporation is lower than with the autograft. Allograft bone also introduces the possibilities of immune rejection and of pathogen transmission from donor to host, and although infrequent, infections could occur in the recipient's body after the transplantation. ${ }^{[30-34,37]}$

As an alternative to these two bone grafts, there are metals and ceramics. ${ }^{[30]}$ However, both of them do present several disadvantages. Metals, for instance, although providing immediate mechanical support at the site of the defect, exhibit poor overall integration with the tissue at the implantation site, and can fail because of infection or secondary due to fatigue loading. ${ }^{[30]}$ On the other hand ceramics have very low tensile strength and are brittle and,

Table 1. Bone cell types and respective functions (Compiled from refs. ${ }^{[7-11]}$ ).

\begin{tabular}{|c|c|c|}
\hline Cell type & Morphological characteristics & Function \\
\hline Osteoblasts & $\begin{array}{l}\text { Cuboidal in shape, polarized and located, with their } \\
\text { precursors, at the bone surface, where they form } \\
\text { a tight layer of cells }\end{array}$ & $\begin{array}{l}\text { Synthesis and regulation of bone ECM deposition and } \\
\text { mineralization } \\
\text { Respond to mechanical stimuli }\end{array}$ \\
\hline Osteocytes & $\begin{array}{l}\text { Stellate shaped } \\
\text { Possess fewer organelles than the } \\
\text { osteoblasts }\end{array}$ & $\begin{array}{l}\text { Calcification of the osteoid matrix } \\
\text { Blood-calcium homeostasis } \\
\text { Mechanosensor cells of the bone }\end{array}$ \\
\hline Osteoclasts & $\begin{array}{l}\text { Polarized cells } \\
\text { Multinucleated cells }\end{array}$ & Bone resorption \\
\hline
\end{tabular}


Table 2. Components of the organic phase of bone matrix (Compiled from refs. ${ }^{[12-25]}$ ).

Bone extracellular

Functions and properties

matrix constituent

Collagen I

Byglican

Decorin

Osteonectin

Thrombospondin

Fibronectin

Osteopontin

Bone Sialoprotein

Osteocalcin

\author{
Provides framework for skeletal structure; matrix calcification \\ Proteoglycan; affect collagen fiber growth and diameter; involved in the process of matrix mineralization \\ Glycoprotein; binds $\mathrm{Ca}^{2+}$ and collagen; nucleates hydroxylapatite \\ Glycoprotein; binds calcium, hydroxylapatite, osteonectin and other cell surface proteins; mediates cell adhesion \\ in a RGD-independent fashion \\ Osteoblast attachment to substrate \\ Sialoprotein; constituent of cement line; involved in bone remodelling; \\ Sialoprotein; constituent of cement line \\ Skeletal gla protein; late marker of osteogenic phenotype; involved in bone remodelling; it may also be involved in \\ the control of mineralization trough its inhibition.
}

thus they cannot be used in locations of significant torsion, bending, or shear stress. ${ }^{[30]}$

Hence it is clearly seen that an adequate bone replacement is yet to be found and it is at the same time urgently needed for full recovery of the patients. A possible solution for these problems may be in TE.

\section{Tissue Engineering}

\subsection{Definition}

As it was defined by Langer and Vacanti, ${ }^{[38]}$ TE is "an interdisciplinary field of research that applies the principles of engineering and the life sciences towards the development of biological substitutes that restore, maintain, or improve tissue function". In contrast to classic biomaterials approach, it is based on the understanding of tissue formation and regeneration, and aims to induce new functional tissues, rather than just to implant new spare parts. ${ }^{[39]}$ Researchers hope to reach this goal by combining knowledge from physics, chemistry, engineering, materials science, biology, and medicine in an integrated manner. ${ }^{[38-40]}$

But, what is required to grow new bone? From a biological perspective you need cells, extracellular matrix, intercellular communications, cells-matrix interactions, and growth factors. However, the mentioned components are not the only issue on bone tissue engineering. Bone has a $3 \mathrm{D}$ configuration, and cells do not grow in a 3D fashion in vitro, so a 3D structure, a scaffold, mimicking bone structure, must be used so that new tissue can be grown in a 3D manner.

For a successful result, all of these single cell components have to be combined in a well-coordinated spatial and time dependent fashion. Furthermore, all of them should possess a number of properties and characteristics that make them suitable for this purpose.

\subsection{Scaffolds - Temporary Matrices for Bone Growth}

Any tissue consists of a matrix and one, or usually, many cell types. The matrix is, in vivo, a 3D scaffold for cells, and provides them with a tissue specific environment and architecture. ${ }^{[39]}$ Furthermore, it serves as a reservoir of water, nutrients, cytokines, growth factors. In this sense, and in order to restore function or regenerate tissues one needs a template, a scaffold, that will act as a temporary matrix for cell proliferation and extracellular matrix deposition, with consequent bone in-growth until the new bony tissue is totally restored/regenerated ${ }^{[39-41]}$ Moreover, they would also act as a template for the vascularization of this neo-tissue ${ }^{[38,39,41]}$ and they could actively participate in the regenerative process through the release of growth/ differentiation factors, present in its structure. ${ }^{[42]}$

It is then logical to say that an appropriate $3 \mathrm{D}$ scaffold is an essential component for a tissue engineering strategy. However, it is important to realize that the latter must have a series of properties that make it suitable for TE purposes. Besides the choice of adequate materials, that will be addressed later, the macro and micro-structural properties of the materials are of utmost importance. ${ }^{[43]}$ Such properties affect not only cell survival, signalling, growth, propagation, and reorganization but also their gene expression and the preservation, or not, of their phenotype. ${ }^{[43]}$

\subsubsection{Scaffolds Essential Properties}

The following properties have been defined has being essential: ${ }^{[39,41-46]}$

\section{Biocompatibility}

Scaffolds should be well integrated in the host's tissue without eliciting an immune response. ${ }^{[41-44]}$

\section{Porosity}

Scaffolds must posses an open pore, fully interconnected geometry in a highly porous structure with large surface to area volume ratios that will allow cell in-growth and an accurate cell distribution throughout the porous structure, and will facilitate the neovascularization of the construct from the surrounding tissue. Furthermore, the scaffolds should also exhibit adequate microposity, in order to allow capillary in-growth. Porosity and interconnectivity are also 
important for an accurate diffusion of nutrients and gases and for the removal of metabolic waste resulting from the activity of the cells that had meanwhile grown into the scaffold. This is of particular importance regarding bone tissue engineering because, due to bone metabolic characteristics, high rates of mass transfer are expected to occur, even under in vitro culture conditions. ${ }^{[46]}$ However, the degree of porosity always influences other properties of the scaffolds such as its mechanical stability, so, its value, should always be balanced with the mechanical needs of the particular tissue that is going to be replaced.

\section{Pore Size}

Pore size is also a very important issue because, if the pores employed are to small, pore occlusion by the cells will happen. This will prevent cellular penetration, extracellular matrix production, and neovascularization of the inner areas of the scaffold.

It is well accepted that for bone tissue engineering purposes, pore size should be within the 200-900 $\mu \mathrm{m}$ range. ${ }^{[4,45,47]}$ However, Holly et al. ${ }^{[48]}$ reported a different concept. In the referred case the authors believe that bone reconstruction will only be achieved by having a 3D temporary matrix with a large macroporous interconnected structure with pore size ranging from $1.2-2.0 \mathrm{~mm}$. This later approach has evident advantages due to its high surface to volume ratios that will facilitate cell, tissue and blood vessels in-growth. However, this affects the mechanical properties avoiding its use in areas which are very demanding from the mechanical point of view.

\section{Surface Properties}

Surface properties, both chemical and topographical, can control and affect cellular adhesion and proliferation. ${ }^{\text {[4-51] }}$ Chemical properties are related with the ability of cells to adhere to the material as well as with the protein interactions with the latter. Topographical properties are of particular interest when the topic is osteoconduction. As defined by Davies et al. ${ }^{[21]}$ osteoconduction is the process by which osteogenic cells migrate to the surface of the scaffold trough a fibrin clot, which is established right after the material implantation. This migration of osteogenic cells trough the clot will cause retraction of the temporary fibrin matrix. Hence, it is of the utmost importance that the fibrin matrix is well secured to the scaffold or, otherwise, when osteogenic cells start to migrate the fibrin will detach from the scaffolds due to wound contraction. It has been previously shown ${ }^{[20,52]}$ that a more "rough" surface will be able to imprison the fibrin matrix, better than a smooth surface, and hence facilitate the migration of osteogenic cells to the materials surface.

\section{Osteoinductivity}

Osteoinduction is the process by which stem and osteoprogenitor cells are recruited to a bone healing site, and stimulated to undergo the osteogenic differentiation pathway. ${ }^{[52]}$ However, when the portion of bone to regenerate is large, natural osteoinduction combined with a biodegradable scaffold may be not enough. Because of this the scaffold should be osteoinductive by itself.

\section{Mechanical Properties and Biodegradability}

In vitro, the scaffolds should have sufficient mechanical strength to withstand the hydrostatic pressures and to maintain the spaces required for cell in-growth and matrix production. ${ }^{[43]}$ In vivo, and because bone is always under continuous stress, the mechanical properties of the implanted construct should ideally match those of living bone, so that an early mobilization of the injured site can be made possible. ${ }^{[41-43]}$ Furthermore, the scaffolds degradation rate must be tuned appropriately with the growth rate of the neotissue, in such a way that by the time the injury site is totally regenerated the scaffold is totally degraded. ${ }^{[38]}$

\subsubsection{Biomaterials used as Bone TE Scaffolds}

The selection of the most appropriate material to produce a scaffold to be used in bone tissue engineering applications is a very important step towards the construction of a tissue engineered product, since its properties will determine, to a great extent, the properties of the scaffold. ${ }^{[53]} \mathrm{Up}$ to now several materials such as metals, ceramics and polymers from both natural or synthetic origins have been proposed. However, metals and most of the ceramics are not biodegradable, which leaves the researcher's choice reduced to a small number of ceramics and to biodegradable polymers.

Ceramics, have been widely used in the biomedical engineering and bone substitution/regeneration field. ${ }^{[54]}$ They can be from natural (e.g., coralline hydroxylapatite (HA)) origin or synthetic such as synthetic HA or $\beta$-tricalcium phosphate $\left(\beta\right.$-TCP). ${ }^{[54]}$ Due to their interesting properties, mainly the fact of being osteoconductive and osteoinductive, they have been considered for bone tissue engineering applications. Several works ${ }^{[34,55-64]}$ have shown that by using ceramics with or without bone marrow cells, good results regarding bone regeneration could be obtained. However, these materials have some major drawbacks. To begin with they are brittle and present a low mechanical stability, which prevents their use in the regeneration of large bone defects. Furthermore, due to factors that happen in vivo, such as osteoclastic activity, their degradation/dissolution rates are difficult to predict. This could present a problem because if it degrades too fast it will compromise the mechanical stability of the construct, which is low by itself. At the same time, this would dramatically increase the extracellular concentrations of $\mathrm{Ca}$ and $\mathrm{P}$, which can cause cellular death, as demonstrated by Adams et al. ${ }^{[65]}$

As an alternative to the above referred materials, there are biodegradable polymers, which are believed to be the ideal 
materials for bone TE. ${ }^{[41,44]}$ These can be divided in two groups: natural and synthetic.

Natural biodegradable polymers are those obtained from natural sources, either from animal or vegetal source. Within these we can find, among others, collagen ${ }^{[66-69]}$ fibrinogen, ${ }^{[70-77]}$ chitosan, ${ }^{[78-86]}$ starch, ${ }^{[74,87-100]}$ hyaluronic acid (HA), ${ }^{[101-103]}$ and poly(hydroxybutyrate). ${ }^{[104,105]}$ The main advantages of these materials are their low immunogenic potential, the potential bioactive behavior and the capability of interacting with the host's tissue, chemical versatility, and in some cases their source, as in starch and chitosan, which is almost unlimited.

Synthetic biodegradable polymers are the ones that are more commonly used within the biomedical engineering field. Their chemical versatility and processability varies according to their structure and nature, and hence a direct comparison with the natural polymers can not be established. The most widely used are poly $(\alpha$-hydroxy acids),${ }^{[106-129]}$ poly( $\varepsilon$-caprolactone) $){ }^{[130-135]}$ poly(propylene fumarates) ${ }^{[127,136-144]}$ poly(carbonates), ${ }^{[145-149]}$ poly(phosphazenes), ${ }^{[127,150-152]}$ and poly(anhydrides). ${ }^{[127,153,154]}$ Further details on the origin and characteristics of these materials can be found in Table 3 .

\subsubsection{Processing Techniques}

The next step after selecting the adequate biodegradable polymer is to develop or choose an adequate processing technique. In order to do so, and to be sure that all the scaffolds characteristics are fulfilled, the chosen processing technique should obey, in general terms, to the following criteria: ${ }^{[43]}$

The processing methodology must not adversely affect the materials properties, namely their biocompatibility or chemical properties.

The technique should be accurate and consistent, regarding porosity, pore size, pore distribution and interconnectivity.

Different scaffold batches should exhibit minimal variations in their properties when processed from the same set of processing parameters and conditions.

Through the years a series of processing techniques such as solvent casting, ${ }^{[106,113,155,156]}$ phase inversion, ${ }^{[48,157]}$ fiber bonding, ${ }^{[158-160]}$ melt based technologies, ${ }^{[91,99,131,161-164]}$ high pressure based methods, ${ }^{[107,165]}$ freeze drying, ${ }^{[166,167]}$ and rapid prototyping technologies ${ }^{[121,130,134,168-178]}$ were developed with the aim of producing scaffolds with adequate properties for bone tissue engineering. A description and discussion on these techniques will be given in the following lines.

Solvent casting/particulate leaching is probably the best known and most widely used method for the preparation of bone tissue engineering scaffolds. It was first described by Mikos et al. in 1994. ${ }^{[106]}$ This method consists in dispersing calibrated mineral (e.g., sodium chloride, sodium tartrate and sodium citrate) or organic (e.g., saccharose) particles in a polymer solution. Yoon et al. ${ }^{[113]}$ reported that effervescent salts such as ammonium hydrogencarbonate and citric acid could also be used. This dispersion is then processed either by casting or by freeze-drying in order to produce porous scaffolds. A variation to this method was reported by Agrawal et al. ${ }^{[155]}$ In this work vibration was used during the dissolution of the polymer in the solvent and during the solvent evaporation. By doing so it was possible to increase the porogen/polymer ratio and avoid crystal deposition. [155] Yet another variation was proposed by Murphy et al. ${ }^{[156]}$ In this particular technique the $\mathrm{NaCl}$ crystals are not mixed with the polymer solution. Instead, the $\mathrm{NaCl}$ crystals are poured into a mould and subjected to $95 \%$ humidity for different periods of time, so salt fusion can be achieved. This technique allows for an increase in pore interconnectivity. ${ }^{[156]}$ The salt particles are eventually leached out by selective dissolution to produce a porous polymer matrix. The porosity depends on the ratio porogen/polymer used and the pore size on the size of the used crystals. It has been reported that by using this methodology it was possible to obtain fully interconnected scaffolds with more than $90 \%$ of porosity. ${ }^{[06,113,155,156]}$ This technique has been validated for poly(L-lactic acid) (PLLA) or poly(lactide-co-glycolide) (PLGA), for which chloroform and methylene chloride were used. However, and as long as it is possible to find an adequate solvent, these technique can be applied to other polymers, as reported by Gomes et al. ${ }^{[99]}$ Scaffolds produced by this methodology have been used in several studies for bone tissue engineering proposes, with relatively good results. ${ }^{[118]}$ However this method presents some disadvantages such as the use of highly toxic solvents ${ }^{[41,44,53]}$ and the limitation to produce only thin wafers or membranes up to $3 \mathrm{~mm}$ thick. ${ }^{[44,53]}$ Furthermore, their mechanical properties are far from being ideal even when compared to those from trabecular bone. ${ }^{[53]}$

Phase inversion/particulate leaching is similar to the previous example. An example of a PLGA scaffold processed by this methodology can be observed in Figure 1. The main difference is that instead of allowing the solvent to evaporate, the solution film is placed in water. This results in a phase inversion which causes the PLGA to precipitate. ${ }^{[48]}$ The main advantage when compared to standard solvent casting is that crystal deposition is avoided and samples thicker than $3 \mathrm{~mm}$ can be produced. Holy et al. ${ }^{[48]}$ reported that when using this technique scaffolds with improved interconnectivity and morphologies similar to trabecular bone could be obtained. Since then, these scaffolds have shown in a number of occasions that they could support osteoblast-like cells growth with consequent bone ECM elaboration. ${ }^{[48,157]}$ However, and excluding the thickness of the samples, these scaffolds present the same disadvantages as those obtained by solvent casting.

Fiber bonding is a scaffold processing technique that consists of individual fibers woven or knitted into three- 
Table 3. Natural and synthetic polymers used for bone tissue engineering applications.

\begin{tabular}{|c|c|c|c|}
\hline Material & Origin & Characteristics & Refs. \\
\hline Collagen & Natural & $\begin{array}{l}\text { Low immune response } \\
\text { Good substrate for cell adhesion } \\
\text { Chemotactic } \\
\text { Scaffolds with low mechanical properties }\end{array}$ & [66-69] \\
\hline Fibrin & Natural & $\begin{array}{l}\text { Promotes cell migration and vascularization } \\
\text { Promotes Osteoconduction } \\
\text { Usually is used as a cell carrier for cell seeding on scaffolds }\end{array}$ & {$[70-77]$} \\
\hline Chitosan & Natural & $\begin{array}{l}\text { Hemostatic } \\
\text { Promotes osteoconduction and wound healing }\end{array}$ & {$[78-86]$} \\
\hline Starch & Natural & $\begin{array}{l}\text { Thermoplastic behavior } \\
\text { Good substrates for cell adhesion } \\
\text { Non-cytotoxic and biocompatible } \\
\text { Bone bonding behavior when reinforced with hydroxylapatite } \\
\text { Scaffolds based on these materials have good mechanical properties }\end{array}$ & {$[74,87-100]$} \\
\hline Hyaluronic acid (HA) & Natural & $\begin{array}{l}\text { Minimal immunogenicity } \\
\text { Chemotactic when combined with appropriate agents } \\
\text { Scaffolds with low mechanical properties }\end{array}$ & {$[101-103]$} \\
\hline Poly(hydroxybutyrate) & Natural & $\begin{array}{l}\text { Natural occurring } \beta \text {-hydroxyacid } \\
\text { Adequate substrate for bone growth } \\
\text { Usefullness is limited due to brittle nature }\end{array}$ & {$[104,105]$} \\
\hline $\operatorname{Poly}(\alpha$-hydroxy acids) & Synthetic & $\begin{array}{l}\text { Extensively studied aliphatic polyesters } \\
\text { Degradation by hydrolysis } \\
\text { Already approved for other health related applications } \\
\text { Acidic by products (e.g. lactic acid, glycolic acid), that enter the } \\
\text { tricarboxylic acid cycle or in alternative (e.g. glycolic acid) } \\
\text { are excreted in the urine } \\
\text { It can present problems regarding biocompatibility and cytotoxicity in the } \\
\text { surrounding area of the implantation site }\end{array}$ & [106-129] \\
\hline Poly(E-caprolactone) & Synthetic & $\begin{array}{l}\text { Aliphatic polyester } \\
\text { Degraded by hydrolysis or bulk erosion } \\
\text { Slow degrading } \\
\text { Degradation products incorporated in the tricarboxylic acid cycle } \\
\text { Low chemical versatility } \\
\text { Some problems related with withstanding mechanical loads }\end{array}$ & {$[130-135]$} \\
\hline Poly(propylene fumarates) & Synthetic & $\begin{array}{l}\text { Unsaturated polyester consisting on alternating propylene glycol } \\
\text { and fumaric acids. } \\
\text { Main degradation products are fumaric acid and propylene glycol } \\
\text { Satisfactory biological results }\end{array}$ & {$[127,136-144]$} \\
\hline Poly(BPA iminocarbonates) & Synthetic & Good biocompatibility when implanted in a bone canine chamber model & [145-149] \\
\hline Poly(phosphazenes) & Synthetic & $\begin{array}{l}\text { Contain alternating nitrogen and phosphorous with no carbon athoms in } \\
\text { the backbone structure } \\
\text { Degradation through hydrolysis }\end{array}$ & {$[150-152]$} \\
\hline Poly(anhydrides) & Synthetic & $\begin{array}{l}\text { Mainly developed as drug delivery carriers } \\
\text { Biocompatible } \\
\text { Support both endosteal and cortical bone regeneration }\end{array}$ & {$[153,154]$} \\
\hline
\end{tabular}

dimensional patterns of variable pore size. Its main advantage is the large surface area, for cell attachment and rapid diffusion of nutrients. ${ }^{[158,159]}$ Interconnected 3D porous scaffolds have been produced by means of firstly aligning poly(glycolic acid) (PGA) fibers in the desired shape, after which they were embedded in a PLLA/methylene chloride solution. ${ }^{[160]}$ After evaporation of the solvent, the PLLAPGA composite was heated above the melting temperatures of both polymers. PLLA was then removed by selective dissolution during cooling, leaving the PGA fibers physically joined at their cross-points. The major drawbacks of this technique are the lack of control of the porosity and pore size, immiscibility of the two polymers and solvent residues in the scaffold which may be harmful to cells and organs. ${ }^{[41,43,44,160]}$

A different way to produce scaffolds is to use the socalled melt based technologies.

One of such technologies is known as melt moulding/ particulate leaching. In this methodology the raw polymer is previously mixed with a porogen and loaded into a mold. ${ }^{[161]}$ This mould is then heated above the glass transition temperature of the chosen polymer, after which the polymer-porogen composite is immersed in a solvent for the selective dissolution of the porogen. ${ }^{[161]}$ In this way 


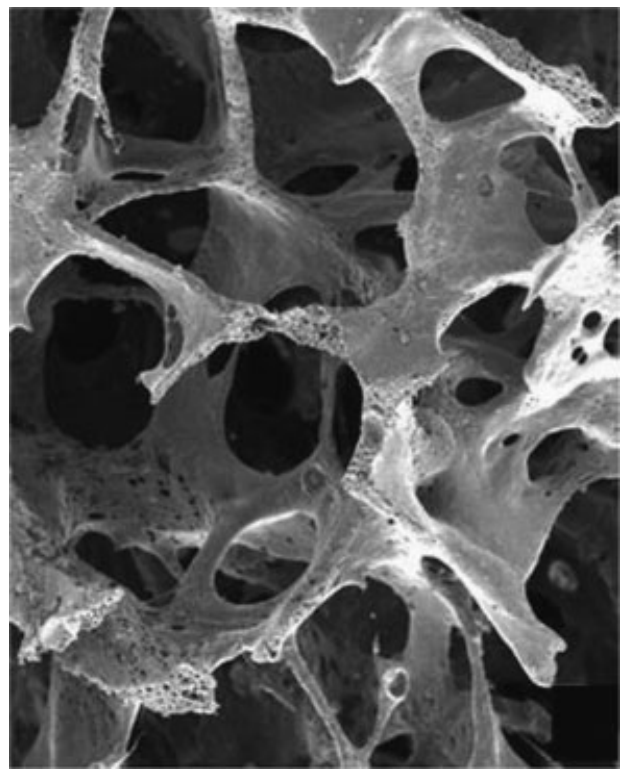

Figure 1. PLGA scaffold (Osteofoam ${ }^{\mathrm{TM}}$ ) obtained by phase inversion. (The image is a kind gift from Mr. Limin Guam and Prof. John E. Davies from the University of Toronto).

3D porous scaffolds of various shapes can be produced by simply changing the mold geometry. ${ }^{[43,160,161]}$ Furthermore, this method also offers independent control of the pore size and porosity, by varying the amount and size of the porogen crystals. ${ }^{[43,160,161]}$

Other melt based techniques used for the processing of scaffolds are extrusion and injection moulding. ${ }^{[91,99]} \mathrm{Al}-$ though these techniques are not usually used for the referred objectives, they have recently been proposed as an alternative for the current methodologies used in the tissue engineering field by Gomes et al. ${ }^{[1,99]}$ This technique is based on the mixture of the raw polymer with a blowing agent based on citric acid. After being mixed the blend undergoes extrusion or is injected into a mould. During the processing the blowing agent will degrade, releasing water and carbon dioxide which will create the pores within the polymeric matrix..$^{[91,99,162-164]}$ By using these methods Gomes et al. ${ }^{[99]}$ were able to obtain scaffolds, based on starch based blends, with $60-70 \%$ porosity and good degrees of interconnectivity, and morphologies similar to those of trabecular bone, as it can be observed in Figure 2. Furthermore, the mechanical properties of those scaffolds, namely the compressive modulus and compressive strength, were similar to those found for trabecular bone, and significantly higher when compared to scaffolds produced by traditional methodologies. ${ }^{[91,99]}$ Besides having good properties from the materials science perspective these scaffolds have also shown to be non cytotoxic, to sustain osteoblastlike cell growth and bone ECM deposition. ${ }^{[74,100]}$ The only drawback of these methodologies is the non-optimized control of pore distribution.

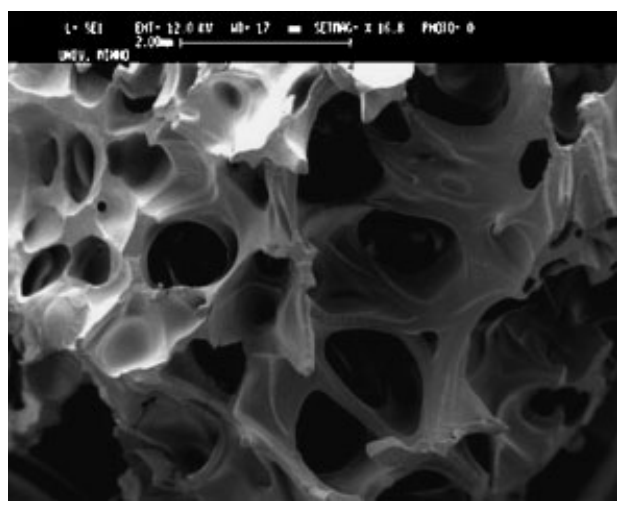

Figure 2. Starch-poly(lactic acid) (SPLA) scaffolds processed by using a methodology based on extrusion with blowing agents.

Still regarding extrusion, other authors have different approaches. ${ }^{[131]}$ Washburn et al. reported on the processing of scaffolds through a co-extrusion methodology. ${ }^{[131]}$ In this work poly( $\varepsilon$-caprolactone) (PCL) was blended with poly(ethylene oxide) in a twin-screw extruder to form a two-phase material with micron-sized domains. After being processed the composite was immersed in water. Through the selective dissolution of the poly(ethylene oxide) it was possible to obtain a porous structure for tissue engineering applications.

High pressure processing is based on the $\mathrm{CO}_{2}$ saturation of polymer disks, through their exposure to high-pressure $\mathrm{CO}_{2} \cdot{ }^{[107]} \mathrm{A}$ thermodynamic instability is then created by reducing the $\mathrm{CO}_{2}$ gas pressure to an ambient level, which results in nucleation and expansion of the dissolved $\mathrm{CO}_{2}$, generating macropores. As described by Money et al. ${ }^{[107]}$ this method has been used to obtain PLGA scaffolds with $93 \%$ of porosity and a pore size in the range of $100 \mu \mathrm{m}$. Scaffolds produced by this methodology have shown to support osteoblast-like cells growth, deposition and mineralization of bone ECM-like matrix. ${ }^{[165]}$ However, they do present several disadvantages such as, low mechanical properties, a non-porous surface and a closed pore structure, which may be problematic for cell and tissue in growth.

The freeze-drying process relies on a thermally induced phase separation, which occurs when the temperature of a homogeneous polymer solution, previously poured into a mold, is decreased. Once the phase-separated system is stabilized, the solvent-rich phase is removed by vacuum sublimation leaving behind the polymeric foam. This methodology has been used to develop scaffolds from natural and synthetic origin. ${ }^{[166,167]}$ Low mechanical stability, sensitivity of the technique (processing parameters have to be very well controlled) and pore sizes in the range of $100 \mu \mathrm{m}$ are their main disadvantages. ${ }^{[41,44]}$

With the advances in computer and processing technology, new methodologies, such rapid prototyping $(R P)^{[41]}$ 
also known as solid freeform fabrication $(S F F),{ }^{[43]}$ have become available for use in the TE field. These methodologies are computerized fabrication techniques that can produce highly complex three dimensional physical objects using data generated by computer assisted design (CAD) systems, computer based medical imaging, digitizers and other data makers. ${ }^{[41,43]}$ RP techniques use the underlying concept of layered manufacturing, whereby $3 \mathrm{D}$ objects are fabricated layer by layer via the processing of solid sheet, liquid or powder material stocks. Customized design, computer controlled fabrications and anisotropic scaffold microstructures are their main advantages for the use in TE. The most used within this field are $3 D$ printing, ${ }^{[168-172]}$ fused deposition modeling (FDM $),{ }^{[130,134]} 3 D$ plotting ${ }^{[173-176]}$ and indirect RP approaches. ${ }^{[121,177,178]}$ Typical examples of scaffolds processed using RP methodologies can be found in Figure 3.

$3 D$ printing was the first RP technique to be proposed for biomedical and tissue engineering purposes. ${ }^{[168,169]}$ This particular technique employs inkjet technology for processing powder materials. ${ }^{[41,43,170]}$ During the fabrication, a

\section{a)}

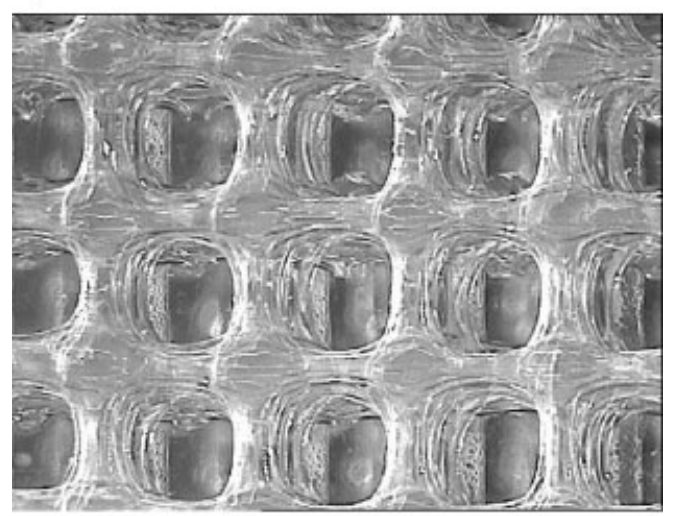

b)

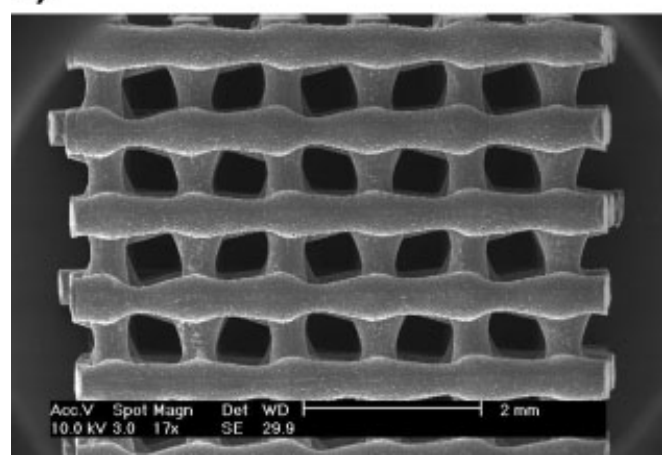

Figure 3. Scaffolds obtained by using rapid prototyping technologies: a) chitosan scaffolds processed by a 3D plotting methodology and b) PCL/PEG scaffolds obtained by Fused Deposition Modelling (Both images are a kind gift from Dr. Dietmar Hutmacher from the National University of Singapore). printer head is used to print a liquid binder onto thin layers of powder following the object's profile as generated by the CAD file. ${ }^{[41,43,170]}$ The subsequent stacking and printing of material layers to the top of previously printed layer recreates the full structure of the desired object, in this case scaffolds for bone tissue engineering. ${ }^{[41,43,170]}$ The entire process is performed under room temperature, which allows the eventual incorporation of growth factors. ${ }^{[41]}$ Scaffolds using different materials, as well as, with different morphologies have been produced by means of using this technique, ${ }^{[169-172]}$ showing good cell-material interactions. ${ }^{[169,170]}$ The main disadvantages of this technique include the fact that the pore size of the fabricated scaffolds is dependent on the powder size of the stock material, closure of the pores by the stock material, and the use of organic solvents as binders for the traditional poly $(\alpha-$ hydroxy acids). Furthermore, and because the final structure is a combination of several stack up powdered layers, the mechanical properties can also be a problem. ${ }^{[41,43]}$

FDM applies a different concept when compared to 3D printing. In this method a small controlled extruder is used, to force out a thermoplastic filament material, that will be deposited onto a platform in a layer-by-layer process. ${ }^{[130,134]}$ The monofilament is moved by two rollers and acts as a piston to drive the semi-molten extrudate through a nozzle tip. Both the two rollers and the nozzle tip constitute the FDM head. At the end of each finished layer, the base of the platform is lowered and the next layer is deposited. The FDM head moves in the $\mathrm{x}-\mathrm{y}$ axes while the platform moves in the $\mathrm{z}$ direction. PCL or PCL-HA scaffolds with honeycomb-like morphologies and different degrees of porosity have been produced by using this technique. ${ }^{[130,134]}$ Both in vitro and in vivo studies have shown that they had the adequate porosity for cell and tissue in growth and survival. ${ }^{[130,134]}$ Shantz et al. ${ }^{[132]}$ also demonstrated that osteoid formation could be obtained when these scaffolds were previously cultured with periostal cells under osteogenic conditions, and further implanted in vivo in a subcutaneous model. The main advantage of FDM is that it does not use organic solvents. The non-incorporation of growth factors and the range of polymers that can be used due the processing requirements (filaments with good diametrical consistency) and temperatures are its main disadvantages. ${ }^{[43]}$

$3 D$ Plotting was first described by Landers et al. ${ }^{[173]}$ and later used to develop alginate, PLGA, chitosan and chitosan-HA based scaffolds. ${ }^{[129,174-176]}$ In a simplistic way, this system is based on a dispenser(s) for the hydrogel, which will be forced to go through the tip of a syringe and laid down on a platform. ${ }^{[173,175,176]}$ Hydrogel formation can be achieved by chemical reaction during feeding of coreactive components placed in two component dispensers, or by plotting one component in a liquid medium containing a coreactive/coagulating component. ${ }^{[176]}$ The main advantages are the possibility of operating at physiological 
conditions, which will allow the incorporation of growth factors or even cells. ${ }^{[176]}$

Chu et al. ${ }^{[177,178]}$ used a different approach, using RP technologies in an indirect route. In this particular work a RP technique called Stereolithography (SL) was used. Like in the other cases, implants were first generated from CAD software and computer tomography (CT) data. The negative images of the designs were then used to build the molds on an SL apparatus with epoxy resins. After that, a reactive ceramic, hydroxylapatite, suspension was cast in the epoxy molds and cured at $85^{\circ} \mathrm{C}$. The molds were then removed by pyrolysis, followed by HA body sintering. Scaffolds presented porosities between $26 \%-52 \%$ and pore sizes between 366 and $968 \mu \mathrm{m} .{ }^{[178]}$ The differences in the pore size and the porosity vary according with the design developed in the CAD software. This concept was also used in the work reported by Tabuas et al. ${ }^{[121]}$ where scaffolds made of PLA and PGA were developed. In this case ceramic molds were used for the polymer infiltration. This method presents the same general advantages of other RP techniques. However it won't allow for the incorporation of growth factors. Furthermore, the mechanical stability of the polymer-based scaffold still needs to be addressed.

\subsection{Cells for Bone Tissue Engineering}

The next step after the development of an adequate porous structure is the choice of a reliable source of cells that allows their isolation and expansion into high numbers. In fact, an ideal cell source should be easily expandable to higher passages, non-immunogeneic and have a protein expression pattern similar to the tissue to be regenerated. ${ }^{[179]}$

\subsubsection{Osteoblasts}

The first, and most obvious choice because of their nonimmunogenicity is the isolation osteoblasts from biopsies taken from the patients (autologous cells), followed by limited expansion in vitro. However this methodology has several limitations: it is time consuming, relatively few cells are available after the dissociation of the tissue and their expansion rates are relatively low, limiting in this way the number of cells available to be seeded on the scaffolds. Furthermore, in certain bone related diseases osteoblasts may not be appropriate for transplantation because their protein expression profile is under the expected values. ${ }^{[179]}$

An alternative to the referred methodology is the use of cells obtained from non-human donors (xenogeneic cells), which would solve the problem of low cell number yields. However, the immunogenicity of these cells, the possibilities of the transmission of infectious agents such as virus and the ethical and social problems related with this issue have refrained the enthusiasm for this approach. ${ }^{[179,180]}$

It is in this context that stem cell biology appears as the most valid and more promising solution. Since its begin- nings, stem cell research has gone a long way, and although a considerable number of questions are yet to be answered, they can be presented as an alternative to the above described approaches.

\subsubsection{Stem Cells}

To begin with, one should ask, "What are stem cells?"

Stem cells are undifferentiated cells with a high proliferation capability, being able of self-renewal, multilineage differentiation and therefore the regeneration of tissues. ${ }^{[181]}$ However, stem cells have varying degrees of differentiation potential. The most primitive derive from the fertilized oocyte (the zygote), more precisely from the very first descendants of the first divisions (two divisions). ${ }^{[182,183]}$ These cells are totipotent, because they are able to form the embryo and the trophoblast of the placenta. Some days later, these cells start to specialize, forming a hollow ball of cells, the blastocyst, and a cluster of cells called the Inner Cell Mass (ICM) from which the embryo derives. ${ }^{[182,183]}$ The ICM cells, also known as embryonic stem cells $(E S)$, are considered to be pluripotent. ${ }^{[182,183]}$ They can differentiate in almost all cells that arise from the three germ lines, but not the embryo because they are not able to give rise to the placenta and supporting tissues. ${ }^{[182,183]}$ Finally, we can find multipotent stem cells, also known as adult stem cells (ASC), in the fully differentiated tissues. ${ }^{[182-184]}$ Theoretically, and opposing to ES, these would only be capable of producing a limited range of differentiated progeny, related to the embryonary origin of the tissue where they are found. ${ }^{[182,183]}$ However, as it will be discussed later, these cells may have a higher degree of differentiation plasticity (differentiation into other cell lineages that are not related with the embryonary origin of the tissue were they are found), then was expected.

The biological mechanisms responsible by the broad developmental potential of stem cells are still not understood. In recent years much emphasis has been placed on the environment in which a stem cell is placed - its "niche". A niche is a subset of tissue cells and extracellular matrix, which favors the existence of the stem cell in the undifferentiated state. Interaction with other cell types and the components of the extracellular matrix are believed to influence the survival and the development of stem cells to the committed lineages. ${ }^{[183,185]}$

\subsubsection{Embryonic Stem Cells}

As it was referred ES cells reside in the ICM of the blastocyst. They were firstly isolated and grown in culture more than 20 years ago. ${ }^{[186,187]}$ Later on it was found that when transferred to early mouse embryos ES cells could give rise to all somatic cell types of the embryo, including the germ line. ${ }^{[188,189]}$ Up to now it was reported the isolation of ES cells from rodents, ${ }^{[186,187,190]}$ primates ${ }^{[191]}$ and human beings. ${ }^{[192,193]}$ 
Undifferentiated ES cells are characterized by two unique properties: ${ }^{[194]}$ the nearly unlimited self-renewal capability and the capacity to differentiate via precursor cells. Other properties are a high alkaline phosphatase activity, the expression of stage specific embryonic antigens, as SSEA-1, the expression of germ-line transcription factor Oct-4, high telomerase activity and the regulation of ES cell self-renewal by cytokines of the IL-6 family.

When kept in culture murine (rodent) ES cells remain undifferentiated in the presence of leukaemia inhibitory factor (LIF) or, in alternative, when cultured with a feeder layer of murine embryonic fibroblasts (MEF). ${ }^{[195]}$ On the other hand, human ES cells need to be cultured on Matrigel or laminin in the presence of MEF conditioned medium. ${ }^{[195]}$ When these factors, or feeder cells are removed, ES cells differentiate spontaneously into aggregates known as embryoid bodies, which are comprised of the derivatives of all three germ layers. ${ }^{[194,195]}$

The differentiation potential of these cells has been reported by several authors, in which cardiomyocytes, ${ }^{[196]}$ haematopoietic cells, ${ }^{[197]}$ endothelial cells, ${ }^{[198,199]}$ neurons, ${ }^{[200,201]}$ chondrocytes, ${ }^{[202,203]}$ adypocytes, ${ }^{[204,205]}$ hepatocytes, ${ }^{[206,207]}$ and pancreatic islets ${ }^{[208]}$ were differentiated from ES cells. Of particular interest for bone tissue engineering was the work reported by Buttery et al. ${ }^{[209]}$ in which osteoblasts were differentiated from ES cells in the presence of dexamethasone.

However, and although they have an enormous potential for biomedical and tissue engineering applications, some questions need to be addressed. To begin with, there is a need to develop methods that allow the direct differentiation of ES cells, their selective differentiation and integration, as well as the tissue specific function of the ES-cellgenerated somatic cells after transplantation. ${ }^{[194]}$ There are two other issues that need to be solved: ${ }^{[194]}$ (i) to assure that ES-cell-derived somatic donor cells are not tumorogenic (it has been known that undifferentiated ES cells give rise to teratomas and teratocarcinomas when implanted in vivo, mainly due to their unlimited proliferation capability) and (ii) the immunological incompatibility between ES-cellgenerated donor cells. This last point could be solved by using the somatic nuclear cloning transfer methodology (SCNT). ${ }^{[182]}$ However, this will only increase the critics against their use, and would raise even more the ethical and social questions, which are probably the most difficult barrier to overcome, in order to use ES cells in regenerative medicine.

\subsubsection{Adult Stem Cells}

ASCs reside in the fully differentiated or adult tissues. Up to now ASCs were found in the bone marrow, ${ }^{[210]}$ periosteum, ${ }^{[211,212]}$ muscle, ${ }^{[213]}$ fat, ${ }^{[214]}$ brain, ${ }^{[215,216]}$ and skin. ${ }^{[217]}$

It was believed that ASCs were developmentally committed and restricted to differentiate only into cell lineages from the tissue in which the stem cell resides. However, recent reports have shown that their degree of differentiation plasticity may be higher than what was expected. ${ }^{[217-220]}$ For instance Bjornson et al. ${ }^{[218]}$ reported that neural stem cells could give rise to lineage committed heamotopoietic precursors. Galli et al. ${ }^{[219]}$ also demonstrated that neural stem cells could differentiate into muscle cells. Toma et al. ${ }^{[217]}$ have also shown that multipotent adult stem cells isolated from the dermis could be differentiated in to brain, muscle and fat cells. Therefore, and although these concepts still need to be further investigated, as elegantly addressed by Catherine M. Verfaille, ${ }^{[221]}$ adult stem cells will have probably an even broader range of applications than what was firstly considered.

In the bone tissue engineering field there has been a special interest in the stem cells located in the bone marrow, known as Mesenchymal Stem Cells (MSC). The idea that bone marrow contained some kind of osteogenic precursor cells started in 1963, when Petrakova et al. ${ }^{[222]}$ showed that by implanting pieces of bone marrow under the renal capsule, it was possible to obtain an osseous tissue. After this Friedenstein and co-workers ${ }^{[223,224]}$ revealed a series of in vivo studies in which it was shown the possible existence of osteogenic stem cells in the bone marrow. To better understand the nature and origin of these cells, they developed a method to isolate fibroblast-like cells from the marrow based on their ability to adhere to tissue culture plastic. ${ }^{[225]}$ Later he coined the term colony-forming units fibroblastic (CFU-F) to describe these cells that were fibroblastic, non-phagocytic and clonogenic in nature. ${ }^{[226]}$

Almost 20 years later, Caplan ${ }^{[227]}$ gave these cells the name they have today, Mesenchymal Stem Cells. In 1994, the same author described that these cells, when placed in the adequate culture conditions, could be differentiated into cells with mesenchymal origin and lately give origin to bone, cartilage, fat, muscle skin, tendon and other tissues of mesenchymal origin, through what was called "The Mesengenic Process". [228]

One of the early problems regarding the study of MSCs was the high heterogeneity of whole bone marrow cultures. In 1992 Haynesworth et al. ${ }^{[229]}$ described a method that, although did not completely solve the heterogeneity problems of the cultures, at least was able to overcome some of the problems of the previous techniques. The methodology is based on the separation of the MSCs through gradient centrifugation, after which cells were plated on tissue culture plastic. In these conditions they presented similar fibroblastic morphology and the same characteristics of the cells described by Friedenstein. ${ }^{[229]}$ In later studies published by several authors these cells were able to develop into distinct terminal and differentiated cells including bone, ${ }^{[210,230-232]}$ cartilage, ${ }^{[210,232-234]}$ fat, ${ }^{[210]}$ and tendon. ${ }^{[235,236]}$

Besides its differentiation potential, MSCs present other important properties. As described by Bruder et al. ${ }^{[237]}$ they can be extensively expanded in vitro. Pittinger et al. ${ }^{[210]}$ also 
showed that with an increased number of passages they did not spontaneously differentiate. Furthermore it has been suggested that these cells may possess immunosuppressive effects which may render them either "immune privileged" or perhaps immunosuppressive roles in vivo, which would make them suitable for allogeneic or xenogeneic transplantation. ${ }^{[238]}$ However, this subject needs to be further investigated.

After more than a decade after the boost on MSC research there is still a question that is constantly made: "Are there any specific markers to distinguish MSCs from other cells in the bone marrow?" Recently several stem cell surface markers for the isolation and characterization of MSCs were described. For instance, antibodies SB10, SH-2, SH-3 and SH-4 were found to bind to MSCs. ${ }^{[239-242]}$ In 1999 Pittinger et al. described that human MSCs were shown to express a homogeneous ( $>98 \%$ purity) non-hematopoietic phenotype ${ }^{\left[{ }^{[10]}\right.}$ Furthermore they were also positive for SH-2, SH3, CD71, CD44 and CD29 receptors. ${ }^{[210]}$ Besides these markers stem cells also express a myriad of cytokine, growth factors, extracellular matrix and adhesion related receptors, which makes difficult the establishment of universal markers for MSCs. ${ }^{[243]}$ In a certain extent, this is due to the heterogeneity of the MSCs cultures, which possess different cell types with multilineage potential. $^{[243]}$

Although MSCs have several advantages regarding their use for tissue engineering, there are still some issues that need to be addressed. For instance, it is known that the percentage of MSCs present in the bone marrow is very low ( 1 in every 100000 cells $)^{[228]}$ which would make the expansion time consuming. New expansion methods can be the solution. Baksh et al. ${ }^{[244]}$ have recently described the expansion of the non-haematopoietic fraction of bone marrow cells by using a dynamic rotating environment. By doing so, and using the appropriate cytokine "cocktail", the expansion rates could be increased when compared to standard culture techniques. ${ }^{[24]}$ The differentiation capability of donors from different ages also needs to be addressed. It has been shown that the numbers as well as the differentiation potential of MSCs was somewhat diminished when these were isolated from elderly patients. ${ }^{[24-247]}$ Finally, like in the ES cells, the knowledge regarding the mechanisms and pathways that lead to the final osteogenic differentiation is still scarce.

Overall it can be said that, for now, MSCs present more advantages than ES cells for use in bone tissue engineering. For instance, the former are already in clinical trials for certain applications, including bone tissue engineering, ${ }^{[248]}$ while the latter still have a long way until they reach that stage.

However it must be noticed that from the moment that some of the answered questions regarding the ES cells are solved, these will be a tremendous source and for sure a boost for TE methodologies.

\subsection{Growth Factors}

Growth factors are cytokines that are secreted by many cell types and function as signalling molecules. ${ }^{[33]}$ The binding of a growth factor to its receptor initiates intracellular signalling that will lead to different events, such as the promotion and/or prevention of cell adhesion, proliferation, migration and differentiation by up-regulating or downregulating the synthesis of several proteins, growth factors and receptors. ${ }^{[33,249]}$ Hence, these molecules are essential for tissue formation and play an important role in TE.

Like other tissue bone does also posses a plethora of growth factors. Within these bone morphogenetic proteins (BMPs), transforming growth factor beta (TGF$\beta$ ), fibroblast growth factors (FGFs), insulin growth factor I and II (IGF I/II), and platelet derived growth factor (PDGF) are the most common and those that have realistically been proposed for bone tissue engineering applications. ${ }^{[249-253]}$ In the following lines a brief review of the characteristics and properties of these growth factors will be made.

In 1965 , Urist ${ }^{[254]}$ made the discovery that demineralized bone matrix (DBM) could induce bone formation when placed ectopically in subcutaneous tissue. This capability was later attributed to a protein called Bone Morphogenic Protein (BMP). ${ }^{[255,256]}$ Nowadays the BMPs are proteins grouped into the TGF- $\beta$ super-family by virtue of their similarities in protein structure and sequence homology with TGF- $\beta$. BMPs are commonly entrapped with the bone matrix. ${ }^{[253]}$ They are also expressed during the early phases of fracture healing. ${ }^{[251]}$ Although there is a vast array of BMPs described in the literature, BMPs 2, 4, 6 and 7 (also called OP-1) are generally considered to be the most osteoinductive. ${ }^{[249,252]}$ During the healing process their expression rates vary causing the up- or downregulation of the expression of other BMPs. ${ }^{[252]}$ Further details on this topic can be found in the review of Yoon and colleagues. ${ }^{[252]}$ It is also known that they can intervene in the expression of other growth factors, such as TGF- $\beta$, or vice-versa. ${ }^{[249]}$ Their main role is to recruit mesenchymal stem cells to the healing site, and then differentiate them into the osteogenic lineage. The mechanisms by which they act on the MSCs is not yet completely understood, but it is known that, for instance, BMP-2 plays an important role in the expression of osteogenic markers such as alkaline phosphatase (ALP) and osteocalcin, through the mitogen activated protein kinase (MAPK) pathway. ${ }^{[257]}$ At the same time it is probably also involved in the expression of the nuclear transcription factor Cbaf-1/Runx 2. ${ }^{[249]}$ BMPs have already been used in preclinical and clinical trials. ${ }^{[258,259]}$ However, and in spite of the fact that good results were achieved, a problem arose from those experiments, the therapeutic dose varied as much as 100 fold, making difficult the task of finding an optimal concentration for human applications. ${ }^{[259]}$ 
Generally speaking, the biological actions of TGF- $\beta$ are very diverse. It has been shown to stimulate cellular proliferation in vitro and to promote cellular hypertrophy and differentiation. ${ }^{[26]}$ TGF- $\beta$ was also shown to block or initiate cellular migration or differentiation. ${ }^{[260]}$ It stimulates osteoblast-like cells to proliferate and promotes collagen production in vitro. ${ }^{[253]}$ In vivo studies have shown that TGF- $\beta$ increases callus formation on the fracture healing site. ${ }^{[261]}$ However, and because it is involved in several cellular events, it is crucial to control its bioavailability as a therapeutic agent. ${ }^{[260]}$

Both IGF genes are expressed by skeletal cells and though IGF I and II have similar effects on bone metabolism, IGF I is more potent than IGF II. ${ }^{[262]}$ Upon injury they are found in the fracture healing sites and it is known that they stimulate type I collagen synthesis and increase matrix apposition rates. ${ }^{[249,262]}$ In addition, they maintain collagen integrity in the bone microenvironment by decreasing collagen synthesis or by decreasing the expression of interstitial collagenase by osteoblasts. ${ }^{[249,262]}$

Besides these, other growth factors have the potential to be used in bone TE applications. Vascular endothelial growth factor (VEGF) is a potent angiogenic factor and is expressed in a variety of highly vascularized tissues. ${ }^{[263,264]}$ It is commonly found in bone fracture healing sites and the plate growth, and regulates vascularization through the recruitment of endothelial cells to the healing site. ${ }^{[249,265]}$ It also plays an important role in the regulation of the interaction between osteogenesis and angiogenesis. FGFs, namely FGF-2, is yet another cytokine involved in the bone remodelling process. It is believed that it is involved in the regulation of the maintenance of the delicate balance between bone forming cells and bone resorbing cells. ${ }^{[233]} \mathrm{It}$ also promotes the development of new blood vessels ${ }^{[249]}$ and has a role on the stimulation of the osteogenic phenotype through the activation of the Cbaf-1/Runx 2 nuclear transcription factor. ${ }^{[266]}$ Finally PDGF can also have a role in the bone regeneration process. It is produced by osteoblasts, platelets and monocytes/macrophages, and it is believed to have a role in the migration of MSCs to the wound healing sites. ${ }^{[267]}$

\subsection{Bioreactors}

As it was said bone is a highly structured mechanically active $3 \mathrm{D}$ tissue. The true biological environment of osteoblasts is thus derived from a dynamic interaction between active cells experiencing mechanical forces and a continuously changing 3D matrix architecture. ${ }^{[268]}$ In order to develop tissue engineered products in vitro it is thus needed to develop adequate cell/scaffold culture systems that mimic the dynamics of the in vivo environment.

Current standard culture techniques are not the most adequate for these purposes mainly for two reasons: ${ }^{[269]}$
1) The transport of low molecular weight metabolites, waste products and other macromolecules occurs mainly through a diffusion process from the center of the scaffold, which is not ideal for the significant metabolic demands by the cells. ${ }^{[26]}$ Ultimately this could lead to the migration of the cells seeded in the inner areas of the scaffold to the surface, where the nutrient concentration is higher. ${ }^{[269]}$ This phenomenon would cause a depletion of the cells in the center of the scaffold, decreasing the osteogenic cell density in these areas and thus affecting osteogenic differentiation. ${ }^{[269]}$ It also would create a sheath of cells on the surface of the scaffold, which could lately lead to the death of cells present in the inner areas of the scaffold, due to nutrient unavailability and accumulation of waste products. It could also prevent tissue in-growth when implanted in vivo.

2) Static cultures do not mimic the dynamics of the in vivo environment found in bone, namely the mechanical stimulation caused by hydrostatic pressure and shear stress. As reviewed by Sikavitsas et al. ${ }^{[3]}$ these factors do affect the behavior of osteocytes at several levels. Furthermore, it has been also demonstrated that mechanical stress could also up-regulate Cbaf-1/Runx2 expression. ${ }^{[266]}$

The design and development of bioreactors is for sure a solution to overcome the above referred problems. Up to now two systems have been preferentially used, spinner flasks and rotating wall vessel reactors (RWVR). Illustrations of these bioreactor systems can be found in Figure 4. In the first one scaffolds are attached to the needles hanging from the lid of the flask, and convective forces generated by a magnetic stirrer bar allow continuous mixing of the media surrounding the scaffolds. ${ }^{[269]}$ The second one is characterized by the maintenance of the cells in a microgravity state $^{[269-271]}$ also presenting a low fluid shear stress. ${ }^{[266]}$ This later approach, cell/scaffolds culturing, in a microgravity state may present some advantages because it avoids cell deposition, and at the same time promotes cellular interactions. ${ }^{[270]}$ However, it is also known that microgravity is deleterious for bone, leading often to losses in total bone mass. ${ }^{[272,273]}$

In a recent work by Sikavitsas et al. ${ }^{[269]}$ the performance of these two bioreactor systems was directly compared. PLGA scaffolds obtained by the solvent casting/particulate leaching technique were seeded with rat bone marrow cells (RBMC) and kept in culture for 21 days. The results revealed that, in the constructs kept in the spinner flasks, RMBC had higher proliferation rates and increased osteogenic differentiation. This was attributed to a better mitigation of the transport limitations on the external surface of the constructs, the exposure of the constructs to shear stress in the spinner flasks and to the collision of the latter with the walls of the RWVR, which traumatized the cells that were on the surface of the scaffold. ${ }^{[269]}$ However, 
a)

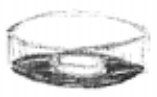

b)

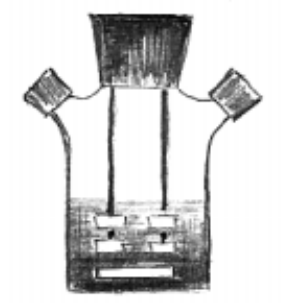

c)

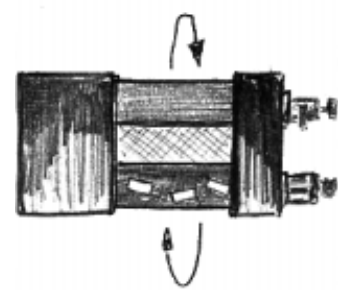

Figure 4. Bioreactors types used in the bone tissue engineering field: a) static; b) spinner flask and c) rotating wall vessel reactors (adapted from ref. ${ }^{[46]}$ ).

there were similar results in one aspect, cells were not homogeneously distributed throughout the scaffolds structure, showing in this way the limitations of the current systems.

As an alternative to the current systems, Bancroft et al. ${ }^{\text {[268] }}$ have recently proposed a bioreactor based on flow perfusion. By using it, it was possible to obtain an accurate cell distribution throughout the scaffold structure. ${ }^{[268]}$ Furthermore, the osteogenic differentiation of RBMCs when seeded on titanium meshes, was also up-regulated when compared to a standard static cell culture system. ${ }^{[268]}$ Similar results were later obtained with SPCL based scaffolds, showing the validity of this system for the use with biodegradable polymers for bone tissue engineering applications. ${ }^{[274]}$

\subsection{Animal Models}

The development of a tissue engineering construct requires the evaluation of its performance on several preclinical studies prior to evaluation in human subjects. Usually the first step taken in this direction is to perform preclinical trials in smaller animals in order to evaluate the proof of concept. If the results are positive the preclinical studies proceed to larger animals. This last option is also closely related to the necessity to evaluate responses of the construct under conditions that better stimulate a physiologic match with the human clinical condition. ${ }^{[275]}$

The appropriate choice of an experimental model, to access the feasibility of a determined tissue engineering concept, is critical to the success of the preclinical studies. The criteria associated with the choice of an experimental model must be related with its functional application, and often with the expected commercial market of the bone tissue engineered construct. ${ }^{[275]}$ The following properties are found to be essential when choosing an animal model: ${ }^{[276]}$

1) It must mimic the clinical setting such that it is biologically analogous and recognizable as an appropriate challenge to human physiology.

2) The bone defect must fail to heal (critical size defect) unless it is treated with the TE strategy under study.

Nevertheless, and before using the more technical challenging bone defects, the researchers can use simpler models, such as ectopic models, namely if the objective is to observe if the developed scaffold has the adequate porosity for tissue and blood vessel in-growth. Within these particular set of tests, the subcutaneous model is the most popular. For this purpose rats are the chosen animals. In the subcutaneous model, scaffolds are normally implanted in the back of the animal. However, materials can also be placed in other ectopical sites such as the muscle, peritoneal cavity, or mesentery. ${ }^{[277]}$ Besides the above referred properties, it is also used to assess the osteoinductivity and ectopic bone formation of scaffolds loaded with growth factors, ceramics and the ability of TE constructs composed by osteogenic cells and scaffolds to induce bone formation. For this latter objective athymic nude mice are commonly used due to the lack of immunogeneic response when using xenogeneic cells (e.g. human MSCs).

There are mainly four types of defects including calvarial, long bone or mandibule segmental, partial cortical (cortical window, wedge defect, or transcortical drill hole) and cancelous bone defects. The commonly used animals are rabbits, rats, dogs and sheep. ${ }^{[277]}$

The cancelous bone defect is made through drilling a hole, for example, in the femur of the rat. It allows the researcher to evaluate the scaffolds' behavior in a "bony" environment namely the level of osteocondunction and bone in-growth.

However, the researcher should have in mind that these models are only useful to test determined proof of concepts, and hence more advanced preclinical models need to be used in order to fully access the feasibility of the TE strategy.

If the objective is to regenerate craniofacial defects the rabbit calvarial model can be used. A critical size defect (CSD) for this model is $15 \mathrm{~mm}$. This model is very popular and appropriate for the following reasons: ${ }^{[277]} 1$ ) the calvarial bone is a plate which allows the creation of a uniform circular defect that enables convenient radiographical and histological analysis; 2) the calvarial bone has a good size for easier surgical procedure and specimen handling; 
3) no fixation is required because of the good supports by the dura and the overlying skin; 4) the model has been thoroughly used and studied, and is well reproduced; 5) it is relatively economical when compared to dogs.

The rat calvarial defect can be used, if rabbits are an expensive option. In this case the CSD is $8 \mathrm{~mm}$. However, there is a major concern about this model, which is the fast healing ability of the rat. ${ }^{[277]}$

In the case of long bone segmental defects the rabbit radial model is also popular and can be used for the following reasons: 1) the radius bone is tubular, which allows the creation of segmental defects that enables convenient radiographical and histological analysis; 2) no fixation is required because of the support of the ulna and 3) is relatively economical. In this case a $15 \mathrm{~mm}$ defect is defined as CSD. ${ }^{[277]}$

If the researcher wants to mimic a clinical application and place the TE construct under a load bearing condition, segmental defects can be performed in the femur of rabbits. However, in this particular approach an internal or external fixation device will be needed.

Pig or sheep models can and should also be used. However its utilization is rare, mainly due to the high costs implied to these models.

In order to evaluate the outcomes of the in vivo assays histological staining methodologies are the common method to assess bone formation. Common histological parameters include the following categories: bone union at the two osteotomies, callus formation, new bone formation of the defect, resorption of the bone graft, marrow changes, and cortex remodelling. Histomorphometric analysis is also another technique that can be used to assess bone formation. By using computerized image analysis it is possible to quantify the area and penetration of bone tissue, area and thickness of non-mineralized bone like tissue, area of osteoblast covered surfaces, thickness of trabeculae, area of fibrovascular tissue, and void space. Finally, radiographic analysis is also very useful to assess bone regeneration, namely if a follow-up procedure is desired. With it, it is possible to obtain information on the amount and quality of the new bone, such as bone density and structure, and continuity with the adjacent recipient bone. ${ }^{\text {[277] }}$

\section{Tissue Engineering Strategies}

The logical assembly of a TE strategy for bone regeneration is ultimately directed by the clinical status of the patient. The basic elements for tissue engineered bone are, as referred above, signalling molecules, cells and matrices for cell growth and differentiation. The combination of these three elements may need to be modified according to several variables such as patient age, gender, health, systemic conditions, habits, and anatomical shape of the implant. Furthermore that same strategy should also adapt itself to the area where the tissue engineering construct is needed, because different regions of the body will have different functional loads and vascularity. ${ }^{[278]}$

Up to now several strategies, from scaffolds alone to 3D matrices loaded with growth factors, have been proposed. In the next lines some will be presented and discussed, especially the ones the authors find more relevant.

Although some materials, namely bioceramics, have shown to be able to induce bone formation without prior cell implantation, it is believed that this strategy could only be used for small defects, where a small amount of circulating MSCs and osteoprogenitors would be needed. This technique would not be successful in the case of large bone defects, due to the high number of those cells that would be needed. ${ }^{[212]}$

Current state of the art within the bone TE field consists of the use of MSCs isolated from the bone marrow combined with $3 \mathrm{D}$ biodegradable porous scaffolds. ${ }^{[34,55,57,60-}$ 63,108,120,279-282] It is known that when exposed to dexamethasone they differentiate towards the osteogenic lineage. ${ }^{[210]}$ To investigate their clinical application several preclinical studies have been performed in the last years.

In 1997 Kadyiala et al. ${ }^{[279]}$ showed that by using MSCs combined with porous ceramics scaffolds it was possible to repair segmental defects in the femora of rats. After 8 weeks substantial new bone formation had occurred, when compared with the control (empty scaffold). Furthermore, bone formation was found in the interface between the host and the construct, and new bone was being formed across the defect. Similar results were later described by Bruder et al. ${ }^{[280]}$ when using a dog model.

Petite et al. ${ }^{[34]}$ used a different animal model, as well as a different strategy. In this particular study a goat model was used. Due to the similarities between the bone remodelling processes between humans and sheep, $25 \mathrm{~mm}$ long defects were created in sheep metatarsals. The scaffold used was a natural calcium carbonate-based ceramic, a coral. Three strategies were experimented: 1) coral alone; 2) fresh bone marrow (FBM) + scaffolds; 3) MSCs + scaffold. MSCs were not cultured with dexamethasone, in order to have them with higher proliferation capability. Results showed that after 16 weeks the defects with scaffold and loaded with $\mathrm{FBM}+$ scaffold did not recover. On the opposite side, defects loaded with scaffold + MSCs, had new bone formation with a tubular pattern, and union between the new and the old bone. Nevertheless two aspects should be pointed out: 1) these results were only obtained for 3 of the 7 animals in which this strategy was used; 2) after 4 months, and although bone union had occurred, the radioopacity of the new bone was not similar to the old bone. The cell densities used and the fact that undifferentiated MSCs were used may explain these results.

Quarto et al. ${ }^{[55]}$ reported a strategy based on multipotent cells isolated from the bone marrow for the recovery of large bone defects (up to $7 \mathrm{~cm}$ ) in three different patients. In this study the MSCs were loaded into macroporous HA 
scaffolds, these having the exact shape of the place where they were going to be implanted. It was not referred whether the cells had been primarily differentiated towards the osteogenic lineage. Two months after the surgeries radiographs and CT scans showed abundant callus formation along the implants and good integration at the interfaces with the host bone by the second month after surgery. According to the authors the healing of the defects was dramatically increased, when compared to the traditional bone graft approach.

The above techniques have at least one aspect in common: they use ceramics as scaffolds. However, as it was previously discussed, they have several disadvantages. In this sense other groups have combined MSCs with polymeric based biodegradable scaffolds.

Ishaug-Riley et al. ${ }^{[108]}$ described in 1997 the formation of bone in ectopic sites through the use of PLGA scaffolds and rat MSCs. Constructs were kept in culture for 7 days under osteogenic conditions and then implanted in the rat mesentery. Bone-like tissue formation was found 7 days after implantation. It was also found vascular tissue adjacent to the islands of bone. After 49 days $11 \%$ of the scaffold structure was filled with bone. However the rate of bone penetration was only around $370 \mu \mathrm{m}$, which may indicate that the porosity and pore interconnectivity were not the most adequate for bone in-growth.

A similar study was conducted by Mendes et al. ${ }^{[281]}$ In this case it was found that bone was being formed on the surface of scaffolds based on a blend of starch with poly(caprolactone) (PCL). The obtained results were in some cases comparable to those obtained with an osteoinductive HA control.

In a recent publication by Holy et al. ${ }^{[282]}$ it was shown that it is possible to induce bone regeneration, by combining cells isolated from the bone marrow with PLGA biodegradable macroporous scaffolds. In this particular study defects of $1.2 \mathrm{~cm}$ were created in rabbit femurs that had been stabilized with titanium reconstruction plates. Defects were left empty, filled with a scaffold, or filled with a tissue engineering construct seeded with autologous bone marrow cells, that had been maintained in culture for 14 days under osteogenic conditions, prior to the surgery. Results revealed that significantly more new bone had formed in the tissue engineered construct group right after 2 weeks. After 6 weeks, $\mathrm{x}$-rays indicated that the defects in these groups showed radio-opacity throughout the entirety of the segmental defects, while only limited radio-opacity was observed in empty and scaffold filled.

Multipotent periostal cells have also been used for the design of TE strategies for bone TE. ${ }^{[56,132,133,212]}$ Within this particular approach it is noteworthy to refer the works reported by Perka et al. ${ }^{[212]}$ and Vacanti et al. ${ }^{[56]}$

In the first case PLGA scaffolds seeded with multipotent cells isolated from the periosteum were placed in critical size defects in the metadiaphyseal ulna of New Zealand white rabbits. After 28 days the constructs had bone formation and adequate transplant integration at the margins to the surrounding bone tissue. Furthermore, new woven bone was in contact with the host lamellar bone. Bridging between the proximal and distal end was also observed, showing that bone had grown through the scaffold structure. ${ }^{[212]}$

The second case is another example of clinical application of TE concepts. Vacanti et al. ${ }^{[56]}$ reported the replacements of an avulsed phalanx. A natural coral scaffold (500 pore Pro-Osteon, Interpore International) filled with periostal cells previously isolated was implanted in the affected area. Twenty-eight months after the implantation the patient had a thumb of normal length and strength, with some sensation. Examination of the implant revealed the latter was vascularized, non-fragmented, and well incorporated into the surrounding tissue. Furthermore, new lamellar bone was found to be in contact with the coral scaffold. However, histomorphometric analysis showed that lamellar bone made only $5 \%$ of the implant, being the rest coral, blood vessels, and soft tissue.

The above referred examples reflect the most common strategies used within the field. Other groups have a different approach, using gene therapy, through genetically modified cells to promote bone healing and reconstruction. ${ }^{[283-285]}$ Gene therapy is a strategy in which nucleic acids, usually DNA, are transferred to somatic cells, resulting in a therapeutic effect by correcting genetic defects, or by expressing therapeutically useful proteins. ${ }^{[286]}$

The common approach in the bone TE field is to transfect cells with the gene encoding for the recombinant BMP-2. ${ }^{[283-285]}$ As reported by Lee et al. ${ }^{[284]}$ by using this strategy it was possible to achieve a higher degree of bone formation when compared to non-transfected cells. Partridge et al. ${ }^{[285]}$ also showed the feasibility of this technique. Osteoprogenitor cells transfected with BMP-2 gene were able to maintain their phenotype when seeded on PLGA scaffolds, and when implanted in vivo were able to induce cell differentiation into the osteogenic lineage and new bone formation.

Particularly interesting are the approaches by Luu et al. ${ }^{[124]}$ Shea et al. ${ }^{[287]}$ and Bonadio et al. ${ }^{[288]}$ in which the scaffold matrix is the vehicle of the desired DNA construct, usually in the form of a plasmid. In vivo experiments have shown that the implantation of gene activated matrices at sites of bone injury was associated with retention and expression of plasmid DNA for at least 6 weeks, and with the induction of normal new bone in a stable, reproducible, dose- and time-dependent manner. ${ }^{[288]}$

This last approach could be more attractive than the more traditional transfection based therapies, mainly due to the existing doubts of the safety of gene therapy, namely when viral vectors are involved. [249]

The use of hydrogel or injectable polymer based strategies have also been addressed. ${ }^{[31,140-144,289]}$ This approach can be useful in areas of difficult access or for 
the regeneration of small defects. However they may not be suitable for the regeneration of large bone defects. Poly(propylene fumarates) based in vivo curing hydrogels have shown promising properties for bone tissue engineering applications. ${ }^{[140-144]}$ Burdick et al. ${ }^{[289]}$ described the use of PEG based hydrogels for the encapsulation of osteogenic cells for bone regeneration. Perka et al. ${ }^{[31]}$ also described a system were fibrin beads or fibrin beads combined with TCP were used for bone regeneration.

However, hydrogels are more commonly used in strategies in which growth factors, such as BMPs, are used. ${ }^{[290]}$ They are particularly interesting for this purpose because of the ease with which the drug is dispersed in the matrix, and the high control achieved by selecting the physical and chemical properties of the polymer structure. ${ }^{[283]}$ The only problem with them is they cannot be used in areas of extreme load bearing.

Because of this 3D scaffolds loaded with a variety of growth factors, from BMPs to PDGF have been used for bone tissue engineering applications. ${ }^{[67,68,82,114,119,291-293]}$ For instance Kokubo et al. ${ }^{[293]}$ use a PLGA coated gelatin sponge to repair $1.5 \mathrm{~cm}$ defects on the ulnar dyaphisis of rabbits. Results showed that after 16 weeks radiographic union was established and the mechanical properties of the bone were restored. In another study collagen sponges loaded with TGF- $\beta 1$ were used to promote repair in skull defects of rabbits ${ }^{[68]}$ Murphy et al. ${ }^{[292]}$ presented a PLGA mineralized scaffold loaded with VEGF. Finally a chitosan sponge loaded with PDGF was also put forward for bone periondotal regeneration. ${ }^{\left[{ }^{82}\right]}$

All the above strategies have advantages and disadvantages. Up to now the most promising has been the one that combines MSCs with 3D scaffolds. However an effort should be made in a near future to combine it with growth factor delivery systems, in order to accomplish a more efficient bone regeneration. This is the approach that we tend to develop in our research group.

\section{Future Trends and Concluding Remarks}

As it was described bone tissue is complex, as well as its various structural arrangements. Bone growth and remodelling involves a plethora of growth factors, recruitment of MSCs, the action of three different mature cell types (osteoblasts, osteocytes and osteoclasts) as well other factors that need yet to be unveiled. At this moment, this is probably one of the most challenging aspects to develop a bioartificial tissue engineered bone. Although a great advance in the knowledge of bone biology has been achieved until now, further steps need to be taken in order to better understand what is needed to develop a commercial tissue engineered bone.

The first need is to further understand how the growth factors interact with each other and with cells, what is their effect, which intracellular pathways are triggered by them and how they can be activated/inactivated. It would be also interesting to look deeper into the migration phenomena that lead cells to a bone healing site. MSC cell and molecular biology should also be further addressed. As it was discussed their potential is tremendous, even when compared to ES cells. Nowadays, the MSCs are the best available cell population for bone tissue engineering. However, the knowledge of the differentiation causes and pathways is still poorly understood and new techniques are needed for their purification and expansion. New sources of cells, mainly those where a high number of osteoprogenitor cells can be isolated, should also be searched in order to overcome some of the limitations of the MSCs isolated from bone marrow. By this the authors do not want to say that ES cells cannot be used. However, in a short term it would be very difficult to use them in clinical trials. Nevertheless, and as it was discussed previously, their potential is tremendous and they will probably be used in the future, together with MSCs, as just another option for bone TE applications.

The second aspect that needs to be improved is related with materials science. A new generation of biodegradable biomaterials is currently being designed, to elicit specific cellular responses at the molecular level. ${ }^{[294]}$ This third generation of biomaterials is based on the molecular modifications of resorbable polymer systems that will later stimulate specific interactions with cell integrins and thereby direct cell proliferation, differentiation and extracellular matrix production and organization. ${ }^{[294-296]}$ Self assembled materials are also another class of materials that can be used for TE purposes. ${ }^{[297-300]}$ Particularly interesting is the work reported by Hartgerink et al. ${ }^{[298]}$ where a $\mathrm{pH}$-induced self-assembly of a peptide-amphiphile was described to make a nanostructured fibrous scaffold reminiscent of extracellular matrix, capable of nucleating hydroxylapatite in an alignment similar to that observed between collagen fibrils and hydroxylapatite crystals in bone. Still another approach can be by surface modification, such as the coating of the scaffolds with Ca-P layers. ${ }^{[301-303]}$ Several authors ${ }^{[304-308]}$ have shown that by doing so it is possible to direct cells to a more osteogenic phenotype. A new generation of scaffolds is also needed, with appropriate porosity, degradation rates, and mechanical properties.

Finally, the last point is the scaffold processing techniques. New RP methodologies have shown to overcome some of the limitations of the existing methods, and are very promising in the future for tissue engineering applications. However, new processing techniques, namely those that allow for the development of scaffolds with improved mechanical properties without influencing the porosity and interconnectivity should be studied and developed. It is also the authors opinion that RP should evolve to the processing of less symmetric type of scaffolds, which would need new software and new RP devices, as for instance new 3D dispensing plotters. 
As a final conclusion it can be said that TE has in fact a tremendous potential to overcome the limitations of the existing therapies for bone replacement. However, the next years will be decisive for the affirmation of TE and the recognition from both the general public and the medical community. Because of this it is necessary to improve the materials and our knowledge of bone and stem cell biology so that the final goal, the production of bone TE products, can be achieved.

Acknowledgement: The authors would like to acknowledge the Portuguese Foundation for Science and Technology through funds from POCTI and/or FEDER programs (PhD scholarship to A. J. S. (SFRH/BD/3139/2000)). The authors would also like to acknowledge Dr. Dietmar W. Hutmacher, from the National University of Singapore, Prof. John E. Davies and Mr. Limin Guam, from the University of Toronto, for kindly helping to obtain images for the present publication, and Mr. Luis Osório for the bioreactors illustrations.

[1] D. W. Sommerfeldt, C. T. Rubin, Eur. Spine J. 2001, 10, S86.

[2] G. A. Rodan, Bone 1992, 13, S3.

[3] V. I. Sikavitsas, J. S. Temenoff, A. G. Mikos, Biomaterials 2001, 22, 2581.

[4] P. A. Hill, M. Orth, Brit. J. Orthod. 1998, 25, 101.

[5] R. Baron, "Primer on the Metabolic Bone Diseases and Disorders of Mineral Metabolism", $2^{\text {nd }}$ edition, Raven Press, New York 1993, p. 3.

[6] J. S. Temenoff, L. Lu, A. G. Mikos, "Bone Engineering", $1^{\text {st }}$ edition, Em squared, Toronto 1999, p. 454.

[7] J. E. Aubin, F. Liau, "Principles of Bone Biology", $1^{\text {st }}$ edition, Academic, San Diego, CA 1996, p. 51.

[8] P. Ducy, T. Schinke, G. Karsenty, Science 2000, 289, 1501.

[9] E. J. Mackie, Int. J. Cell Biochem. \& Cell Biol. 2003, 1301.

[10] P. J. Nijweide, E. H. Burger, J. K. Nulend, A. Van der Plas, "Principles of Bone Biology", $1^{\text {st }}$ edition, Academic, San Diego, CA 1996, p. 115.

[11] K. Vaananen, "Principles of Bone Biology", $1^{\text {st }}$ edition, Academic, San Diego, CA 1996, p. 103.

[12] J. Rossert, B. De Crombrugghe, "Principles of Bone Biology", $1^{\text {st }}$ edition, Academic, San Diego, CA 1996, p. 127.

[13] J. T. Triffit, "Principles of Bone Biology", $1^{\text {st }}$ edition, Academic, San Diego, CA 1996, p. 39.

[14] J. D. Termine, "Primer on the Metabolic Bone Diseases and Disorders of Mineral Metabolism", $2^{\text {nd }}$ edition, Raven Press, New York 1993, p. 21.

[15] P. G. Robey, "Principles of Bone Biology", $1^{\text {st }}$ edition, Academic, San Diego, CA 1996, p. 155.

[16] J. Sodek, B. Ganss, M. D. McKee, Crit. Rev. Oral Bio. Med. 2000, 11, 279.

[17] A. L. Boskey, "Dynamics of Bone and Cartilage Metabolism", $1^{\text {st }}$ edition, Academic, San Diego, CA 1999, p. 153.

[18] J. Sodek, S. Cheifetz, "Bone Engineering", $1^{\text {st }}$ edition, Em squared, Toronto 1999, p. 31.
[19] W. T. Buttler, A. L. Ridall, M. D. McKee, "Principles of Bone Biology", $1^{\text {st }}$ edition, Academic, San Diego, CA 1996, p. 167.

[20] J. E. Davies, Anat. Record 1996, 245, 426.

[21] J. E. Davies, Int. J. Prosthodont. 1998, 11, 391.

[22] J.E. Davies, N. Baldan, J. Biomed. Mater. Res. 1997, 36, 429.

[23] S. C. Marks, Jr., D. C. Hermey, "Principles of Bone Biology", $1^{\text {st }}$ edition, Academic, San Diego, CA 1996, p. 3.

[24] S. Weiner, H. D. Wagner, Annu. Rev. Mater. Sci. 1998, 28, 271.

[25] S. Weiner, W. Traub, H. D. Wagner, J. Struct. Biol. 1999, 126, 241.

[26] A. L. Boskey, "Proceedings of the Second International Conference on the Chemistry and Biology of Mineralized Tissues", p. 335.

[27] E. D. Eanes, Prog. Crystal Growth Charact. 1980, $3,3$.

[28] J. Christofferson, W. J. Landis, Anat. Rec. 1991, 230, 435.

[29] K. Yagami, J. Y. Suh, M. Enomoto-Iwamoto, E. Koyama, W. R. Abrams, I. M. Shapiro, M. Pacifici, M. Iwamoto, J. Cell Biol. 1999, 147, 1097.

[30] M. J. Yaszemski, J. B. Oldham, L. Lu, B. L. Currier, “Bone Engineering", $1^{\text {st }}$ edition, Em squared, Toronto 1994, p. 541.

[31] R. Spitzer, C. Perka, K. Lindenhayn, H. Zippel, J. Biomed. Mater. Res. 2002, 59, 690.

[32] G. C. Simon, C. A. Khatri, S. A. Wight, F. W. Wang, J. Orthop. Res. 2002, 20, 473.

[33] F. R. Rose, R. O. Oreffo, Biochem. Biophys. Res. Commun. 2002, 292, 1 .

[34] H. Petite, V. Viateau, W. Bensaid, A. Meunier, C. de Pollak, M. Bourguignon, K. Oudina, L. Sedel, G. Guillemin, Nature Biotech. 2000, 18, 959.

[35] I. Asahina, I. Seto, M. Oda, E. Marukawa, A. M. Imranul, S. Enomoto, "Bone Engineering", $1^{\text {st }}$ edition, Em squared, Toronto 1999, p. 526.

[36] G. P. Reece, C. W. Patrick, Jr., "Frontiers in Tissue Engineering", $1^{\text {st }}$ edition, Pergamon, Oxford 1998, p. 166.

[37] D. F. Williams, "Bone Engineering", $1^{\text {st }}$ edition, Em squared, Toronto 1999, p. 577.

[38] R. Langer, J. P. Vacanti, Science 1993, 260, 920.

[39] U. Kneser, D. J. Schaefer, B. Munder, C. Klemt, C. Andree, G. B. Stark, Min. Invas. Ther. Allied Technol. 2002, 11, 107.

[40] C. T. Laurencin, A. M. A. Ambrosio, M. D. Borden, J. A. Cooper, Jr., Annu. Rev. Biomed. Eng. 1999, 1, 19.

[41] D. W. Hutmacher, Biomaterials 2000, 21, 2259.

[42] C. M. Agrawal, R. B. Ray, J. Biomed. Mater. Res. 2001, 55, 141.

[43] K. F. Leong, C. M. Cheah, C. K. Chua, Biomaterials 2003, 24, 3262.

[44] S. Yang, K. F. Leong, Z. Du, C. K. Chua, Tissue Eng. 2001 , 7, 679 .

[45] V. Maquet, R. Jerome, Mater. Sci. Forum 1997, 250, 15.

[46] L. E. Freed, G. VunjakNovakovic, Adv. Drug. Delivery Rev. 1998, 33, 15.

[47] K. J. Burg, S. Porter, J. F. Kellam, Biomaterials 2000, 21, 2347.

[48] C. E. Holly, M. S. Schoichet, J. E. Davies, J. Biomed. Mater. Res. 2000, 51, 376.

[49] R. Lange, F. Luthen, U. Beck, J. Rychly, A. Baumann, B. Nebe, Biomol. Eng. 2002, 19, 255.

[50] W. He, K. E. Gonsalves, N. Batina, D. B. Poker, E. Alexander, M. Hudson, Biomed. Dev. 2003, 5, 101. 
[51] C. Cassineli, M. Morra, G. Bruzzone, A. Carpi, G. Di Santi, R. Giardino, M. Fini, Int. J. Oral Maxillofac. Impl. 2003, $18,46$.

[52] T. Albrektsson, C. Johansson, Eur. Spine J. 2001, 10, S96.

[53] M. E. Gomes, A. J. Salgado, R. L. Reis, "Polymer Based Systems on Tissue Engineering, Replacement and Regeneration", $1^{\text {st }}$ edition, Kluwer, Dordrecht, The Netherlands 2002, p. 221.

[54] R. Z. LeGeros, Clin. Orthop. Relat. Res. 2002, 395, 81.

[55] R. Quarto, M. Mastrogiacomo, R. Cancedda, S. M. Kutepov, V. Mukhachev, A. Lavroukov, E. Kon, M. Marcacci, New Eng. J. Med. 2001, 344, 385.

[56] C. A. Vacanti, L. J. Bonassar, M. P. Vacanti, J. Shufflebarger, New Eng. J. Med. 2001, 344, 1511.

[57] D. Baksh, J. E. Davies, S. Kim, J. Mater. Sci.: Mater. Med. 1998, 9, 743.

[58] M. D. Grynpas, R. M. Pilliar, R. A. Kandel, R. Renlund, M. Filiaggi, M. Dumitriu, Biomaterials 2002, 23, 2063.

[59] K. G. Marra, J. W. Szem, P. N. Kumta, P. A. DiMilla, L. E. Weiss, J. Biomed. Mater. Res. 1999, 47, 324.

[60] J. A. Dong, T. Uemura, Y. Shirasaki, T. Tateishi, Biomaterials 2002, 23, 4493.

[61] S. C. Mendes, M. Sleijster, A. van den Muysenberg, J. D. de Bruijn, C. A. van Blitterswijk, J. Mater. Sci.: Mater Med. 2002, 13, 575.

[62] J. Dong, H. Kojima, T. Uemura, M. Kikuchi, T. Tateishi, J. Tanaka, J. Biomed. Mater. Res. 2001, 57, 208.

[63] T. Yoshikawa, H. Ogushi, H. Nakajima, E. Yamada, K. Ichijima, S. Tamai, T. Ohta, Transplantation 2000, 69 , 128.

[64] T. Yoshikawa, H. Ogushi, T. Uemura, H. Nakajima, K. Ichijima, S. Tamai, T. Tateisi, Biomed. Mater. Eng. 1998, 5, 311.

[65] C. S. Adams, K. Mansfield, R. L. Perlot, I. M. Shapiro, J. Biol. Chem. 2001, 276, 20316.

[66] D. A. Deporter, N. Komori, T.P. Howley, A. Shiga, A. Ghent, P. Hensel, K. Parisien, Calcif. Tissue Int. 1988, 42, 321.

[67] M. Murata, B. Z. Huang, T. Shibata, S. Imai, N. Nagai, M. Arisue, Int. J. Oral Maxillofac. Surg. 1999, 28, 232.

[68] H. Ueda, L. Hong, M. Yamamoto, K. Shigeno, M. Inoue, T. Toba, M. Yoshitani, T. Nakamura, Y. Tabata, Y. Shimizu, Biomaterials 2002, 23, 1003.

[69] E. Sachlos, N. Reis, C. Ainsley, B. Derby, J. T. Czernuszka, Biomaterials 2003, 24, 1487.

[70] A. Haisch, A. Loch, J. David, A. Pruss, R. Hansen, M. Sittinger, Med. Biol. Eng. Comp. 2000, 38, 686.

[71] P. Tayapongsak, D. A. O'Brien, C. B. Monteiro, L. Y. Arceo-Diaz, J. Oral Maxillofac. Surg. 1994, 52, 161.

[72] M. Hojo, S. Inokuchi, M. Kidokoro, N. Fukuyama, E. Tanaka, C. Tsuji, M. Myasaka, R. Tanino, H. Nakazawa, Plast. Reconstr. Surg. 2003, 111, 1638.

[73] R. M. Senior, W. F. Skogen, G. L. Griffin, G. D. Wilner, J. Clin. Invest. 1986, 77, 1014.

[74] A. J. Salgado, M. E. Gomes, A. Chou, O. P. Coutinho, R. L. Reis, D. W. Hutmacher, Mater. Sci. Eng. C 2002, 20, 27.

[75] M. Endres, J. T. Schantz, A. J. Salgado, C. Kaps, J. Ringe, T. C. Lim, R. L. Reis, M. Sittinger, D. W. Hutmacher, Tissue Eng. 2003, 9, 689.

[76] Q. Huang, J. C. Goh, D. W. Hutmacher, E. H. Lee, Tissue Eng. 2002, 8, 469.

[77] R. Shmelzeisen, R. Schimming, M. Sittinger, J. Craniomaxillofac. Surg. 2003, 31, 34.

[78] M. Zhang, A. Haga, H. Sekiguchi, S. Hirano, Int. J. Biol. Macromol. 2000, 27, 99.
[79] A. Tolaimate, J. Desbrieres, M. Rhazi, A. Alagui, Polymer 2003, 44, 7939.

[80] F. Zhao, Y. Yin, W. W. Lu, J. C. Leong, W. Zhang, J. Zhang, M. Zhang, K. Yao, Biomaterials 2002, 23, 3227.

[81] A. Rezania, K. E. Healy, J. Biomed. Mater. Res. 2000, 52, 595.

[82] Y. J. Park, Y. M. Lee, S. N. Park, S. Y. Sheen, C. P. Chung, S. J. Lee, Biomaterials 2000, 21, 153.

[83] Y. M. Lee, Y. J. Park, S. J. Lee, Y. Ku, S. B. Han, S. M. Choi, P. R. Klokkevold, C. P. Chung, J. Periodontol. 2000, $71,410$.

[84] Y.Zhang, M. Ni, M. Zhang, B. Ratner, Tissue Eng. 2003, 9, 337.

[85] E. T. Baran, K. Tuzlagoklu, A. J. Salgado, R. L. Reis, J. Mater. Sci.: Mater. Med. 2004, 15, 161.

[86] K. Tuzlagoklu, C. M. Alves, J. F. Mano, R. L. Reis, Macromol. Biosci., accepted for publication.

[87] R. L. Reis, A. M. Cunha, "Biological and Biomimetic Materials", in Encyclopedia of Materials Science and Technology, K. H. J. Buschow, R. W. Cahn, M. C. Flemings, B. Ilschner, E. J. Kramer, S. Mahajan, Eds., Pergamon - Elsevier Science, Amsterdam 2001, p. 8810.

[88] R. L. Reis, A. M. Cunha, J. Mater. Sci.: Mater. Med. 1995, 6, 786.

[89] C. S. Pereira, A. M. Cunha, R. L. Reis, B. Vasquez, J. SanRoman, J. Mater. Sci.: Mater. Med. 1998, 9, 825 .

[90] R. A. Sousa, G. Kalay, R. L. Reis, A. M. Cunha, M. J. Bevis, J. Appl. Polym. Sci. 2000, 77, 1303.

[91] M. E. Gomes, A. S. Ribeiro, P. B. Malafaya, R. L. Reis, A. M. Cunha, Biomaterials 2001, 22, 883.

[92] M. E. Gomes, R. L. Reis, A. M. Cunha, C. A. van Blitterswijk, J. D. de Bruijn, Biomaterials 2001, 22, 1991.

[93] S. C. Mendes, R. L. Reis, Y. P. Bovell, A. M. Cunha, C. A. van Blitterswijk, J. D. de Bruijn, Biomaterials 2001, 22, 2014.

[94] A. P. Marques, R. L. Reis, J. A. Hunt, Biomaterials 2002 , 23, 1471.

[95] P. B. Malafaya, C. Elvira, A. Gallardo, J. San Roman, R. L. Reis, J. Biomater. Sci., Polym. Ed. 2001, 12, 1227.

[96] C. Elvira, J. F. Mano, J. San Roman, R. L. Reis, Biomaterials 2002, 23, 1955.

[97] I. Espigares, C. Elvira, J. F. Mano, B. Vasquez, J. San Roman, R. L. Reis, Biomaterials 2002, 23, 1883

[98] L. F. Boesel, J. F. Mano, R. L. Reis, J. Mater. Sci.: Mater. Med., submitted.

[99] M. E. Gomes, J. S. Godinho, D. Tchalamov, R. L. Reis, A. M. Cunha, Mater. Sci. Eng. C 2002, 20, 19.

[100] A. J. Salgado, O. P. Coutinho, R. L. Reis, Tissue Eng. 2004, 10, 465 .

[101] J. H. Brekke, J. M. Toth, J. Biomed. Mater. Res. 1998, 43, 380.

[102] L. S. Liu, A. Y. Thompson, M. A. Heidaran, J. W. Poser, R. C. Spiro, Biomaterials 1999, 20, 1097.

[103] L. A. Solchaga, J. E. Dennis, V. M. Goldberg, A. I. Caplan, J. Orthop. Res. 1999, 17, 205.

[104] L. Kostopoulos, T. Karring, Clin. Oral Implants Res. 1994, 5,75 .

[105] L. J. Chen, M. Wang, Biomaterials 2002, 23, 2631.

[106] A. G. Mikos, A. J. Thorsen, L. A. Czerwonka, Y. Bao, R. Langer, D. N. Winslow, J. P. Vacanti, Polymer 1994, 35, 1068.

[107] D. J. Mooney, D. F. Baldwin, N. P. Suh, J. P. Vacanti, R. Langer, Biomaterials 1996, 17, 1417. 
[108] S. L. IshaughRiley, G. M. Crane, A. Gurlek, M. J. Miller, A. W. Yasko, M. J. Yaszemski, A. G. Mikos, J. Biomed. Mater. Res. 1997, 36, 1.

[109] R. Malekzadeh, J. O. Hollinger, D. Buck, D. F. Adams, B. S. McAllister, J. Periodontol. 1998, 69, 1256.

[110] R. C. Thomson, A. G. Mikos, E. Beham, J. C. Lemon, W. C. Satterfield, T. B. Aufdemorte, M. J. Miller, Biomaterials 1999, 20, 2007.

[111] W. L. Murphy, D. H. Khon, D. J. Mooney, J. Biomed. Mater. Res. 2000, 50, 50.

[112] P. X. Ma, J. W. Choi, Tissue Eng. 2001, 7, 23.

[113] J. J. Yoon, T. G. Park, J. Biomed. Mater. Res. 2001, 55, 401.

[114] N. Saito, T. Okada, H. Horiuchi, N. Murakami, J. Takahashi, M. Nawata, H. Ota, K. Nozaki, K. Takaoka, Nature Biotechnol. 2001, 19, 332.

[115] C. J. Liao, C. F. Chen, J. H. Chen, S. F. Chiang, Y. J. Lin, K. Y. Chang, J. Biomed. Mater. Res. 2002, 59, 676.

[116] S. F. El-Amin, M. Attawia, H. H. Lu, A. K. Shah, R. Chang, N. J. Hickok, R. S. Tuas, C. T. Laurencin, J. Orthop. Res. 2002, 20, 20.

[117] S. H. Choi, T. G. Park, J. Biomater. Sci., Polym. Ed. 2002, 13, 1163 .

[118] K. Ochi, G. Chen, T. Ushida, S. Gojo, K. Segawa, H. Tai, K. Ueno, H. Ohkawa, T. Mori, A. Yamaguchi, Y. Toyama, J. Hata, A. Umezawa, J. Cell Physiol. 2003, 194, 45.

[119] X. Yang, R. S. Tare, K. A. Partdrige, H. I. Roach, N. M. Clarke, S. M. Howdle, K. Shakesff, R. O. Oreffo, J. Bone. Miner. Res. 2003, 18, 47.

[120] H. Abukawa, H. Terai, D. Hannouche, J. P. Vacanti, L. B. Kaban, M. J. Troulis, J. Oral Maxillofac. Surg. 2003, 61, 94.

[121] J. M. Taboas, R. D. Maddox, P. H. Krebsbach, S. J. Hollister, Biomaterials 2003, 24, 181.

[122] E. Lieb, J. Tessmar, M. Hacker, C. Fischbach, D. Rose, T. Blunk, A. G. Mikos, A. Gopferich, M. B. Shulz, Tissue Eng. 2003, 9, 71.

[123] S. F. Almin, H. H. Lu, Y. Khan, J. Burems, J. Mitchell, R. S. Tuan, C. T. Laurencin, Biomaterials 2003, 24, 1213.

[124] Y. K. Luu, K. Kim, B. S. Hsiao, B. Chu, M. Hadjiargyrou, J. Controlled Release 2003, 89, 341.

[125] Y. C. Wang, M. C. Lin, M. Wang, H. J. Hsieh, Biomaterials 2003, 24, 1047.

[126] G. Vozzi, C. Flaim, A. Ahluwalia, S. Bhatia, Biomaterials 2003, 24, 2533

[127] E. Behravesh, A. Yasko, P. Engel, A. G. Mikos, Clin. Orthop. 1999, 367S, S118.

[128] D. B. Thordarson, G. Hurvitz, Foot Ankle Int. 2002, 23, 1003.

[129] H. Peltoniemi, N. Ashammakhi, R. Kontio, T. Waris, A. Salo, C. Lindqvist, K. Gratz, R. Suuronen, Oral Surg. Oral Med. Oral Pathol. Oral Radiol. \& Endodont. 2002, 94, 5.

[130] D. W. Hutmacher, J. T. Schantz, I. Zein, K. W. Ng, S. H. Teoh, K. C. Tan, J. Biomed. Mater. Res. 2001, 55, 203.

[131] N. R. Washburn, C. G. Simon, Jr., A. Tona, H. M. Elgendy, A. Karim, E. J. Amis, J. Biomed. Mater. Res. 2002, 60, 20.

[132] J. T. Shantz, D. W. Hutmacher, K. W. Ng, H. L. Khor, T. C. Lim, S. H. Teoh, Int. J. Oral Maxillof. Implant. 2002, 17, 161.

[133] J. T. Schantz, D. W. Hutmacher, H. Chim, K. W. Ng, T. C. Lim, S. H. Teoh, Cell Transplant. 2002, 11, 125.

[134] I. Zein, D. W. Hutmacher, K. C. Tan, S. H. Teoh, Biomaterials 2002, 23, 1169.

[135] H. Kweon, M. K. Yoo, I. K. Park, T. H. Lim, H. C. Lee, H. S. Lee, J. S. Oh, T. Akaike, C. S. Chi, Biomaterials 2003, 24,801 .
[136] A. K. Shun, M. D. Timmer, S. Jo, P. S. Engel, A. G. Mikos, J. Biomater. Sci., Polym. Ed. 2002, 13, 95.

[137] S. He, M. D. Timmer, M. J. Yaszemski, A. W. Yasko, P. S. Engel, A. G. Mikos, Polymer 2001, 42, 1251.

[138] S. He, M. J. Yaszemski, A. W. Yasko, P. S. Engel, A. G. Mikos, Biomaterials 2000, 21, 2389.

[139] E. Behravesh, S. Jo, K. Zygourakis, A. G. Mikos, Biomacromolecules 2002, 3, 374.

[140] K. Tanahashi, A. G. Mikos, J. Biomed. Mater. Res. 2002, 62,558 .

[141] A. K. Shung, E. Behravesh, S. Jo, A. G. Mikos, Tissue Eng. 2003, 9, 243.

[142] H. Sim, J. S. Temenoff, A. G. Mikos, Biomacromolecules 2003, 4, 552.

[143] J. P. Fisher, J. W. Vehof, D. Dean, J. P. van der Warden, T. A. Holland, A. G. Mikos, J. A. Jansen, J. Biomed. Mater. Res. 2002, 59, 547.

[144] H. Sin, P. Quinten Ruhe, A. G. Mikos, J. A. Jansen, Biomaterials 2003, 24, 3201.

[145] J. Khon, R. Langer, Biomaterials 1986, 7, 176.

[146] C. Li, J. Khon, Macromolecules 1989, 22, 2029.

[147] S. Pulapuras, C. Li, J. Khon, Biomaterials 1990, 11, 666.

[148] J. Choueka, J. L. Charvet, K. J. Koval, H. Alexander, K. S. James, K. A. Kooper, J. Khon, J. Biomed. Mater. Res. 1996, 31,35 .

[149] S. I. Ertel. J. Khon, M. C. Zimmerman, J. R. Passos, J. Biomed. Mater. Res. 1995, 29, 1337.

[150] C. T. Laurencin, M. E. Norman, H. M. Elgendy, S. F. El-Amin, H. R. Allcock, S. R. Pucher, A. M. A. Ambrosio, J. Biomed. Mater. Res. 1993, 27, 963.

[151] S. E. Ibim, A. M. A. Ambrosio, M. S. Kwon, S. F. El-Amin, H. R. Allcock, C. T. Laurencin, Biomaterials 1997, 18, 1565.

[152] C. T. Laurencin, S. F. El-Amin, S. E. Ibim, D. A. Willoghby, M. Attawia, H. R. Allcock, A. M. A. Ambrosio, J. Biomed. Mater. Res. 1996, 30, 133.

[153] S. E. Ibim, K. E. Uhrich, M. Attawia, V. R. Shastri, S. F. El-Amin, R. Bronson, R. Langer, C. T. Laurencin, J. Biomed. Mater. Res. 1998, 43, 374.

[154] K. E. Uhrich. S. E. Ibim, D. R. Larrier, R. Langer, C. T. Laurencin, Biomaterials 1998, 19, 2045.

[155] C. M. Agrawal, J. S. Mckinney, D. Huang, K. A. Athanasiou, "Synthetic Bioabsorbable Polymers for Implants", $1^{\text {st }}$ edition, ASTM, Philadelphia 2000.

[156] W. L. Murphy, R. G. Dennis, J. L. Kileney, D. J. Mooney, Tissue Eng. 2002, 8, 43.

[157] J. M. Karp, M. S. Shoichet, J. E. Davies, J. Biomed. Mater. Res. 2003, 64A, 388.

[158] A. G. Mikos, Y. Bao, L. G. Cima, D. E. Ingber, J. P. Vacanti, R. Langer, J. Biomed. Mater. Res. 1993, 27, 183.

[159] B. S. Kim, D. J. Mooney, J. Biomed. Mater. Res. 1998, $41,322$.

[160] L. C. Lu, A. G. Mikos, MRS Bull. 1996, 21, 28.

[161] R. C. Thomson, M. J. Yaszemski, J. M. Powers, A. G. Mikos, J. Biomater. Sci., Polym. Ed. 1995, 7, 23.

[162] M. E. Gomes, J. S. Godinho, R. L. Reis, A. M. Cunha, J. Appl. Med. Polym. 2002, 6, 75.

[163] P. B. Malafaya, M. E. Gomes, A. J. Salgado, R. L. Reis, "Tissue Engineering, Stem Cells and Gene Therapies", $1^{\text {st }}$ edition, Kluwer Academic/Plenum Publishers, London 2002, p. 201.

[164] M. E. Gomes, P. B. Malafaya, R. L. Reis, "Biopolymer Methods in Tissue Engineering", in: Methods in Molecular Biology Series, A. P. Hollander, P. V. Hatton, Eds., The Humana Press Inc., Totowa 2003, p. 65. 
[165] L. D. Shea, D. Wang, R. T. Franceschi, D. J. Mooney, Tissue Eng. 2000, 6, 605.

[166] P. B. Malafaya, R. L. Reis, “Key Engineering Materials”, Trans Tech Pub, Zurich 2003, 240-2, 39.

[167] J. S. Mao, L. G. Zhao, Y. J. Yin, K. D. Yao, Biomaterials 2003, 24, 1067 .

[168] F. Shen, Y. L. Cui, L. F. Yang, K. D. Yao, X. H. Dong, W. Y. Jia, H. D. Shia, Polym. Int. 2000, 49, 1596.

[169] L. G. Cima, J. P. Vacanti, C. Vacanti, D. Ingber, D. Mooney, R. Langer, J. Biomechan. Eng. 1991, 113, 143.

[170] A. Park, B. Wu, L. G. Griffith, J. BioMater. Sci., Polym. Ed. 1998, $9,89$.

[171] C. X. F. Lam, X. M. Mo, S. H. Teoh, D. W. Hutmacher, Mater. Sci. Eng. C 2002, 20, 49.

[172] J. K. Sherwood, S. L. Riley, R. Palazzolo, S. C. Brown, D. C. Monkhouse, M. Coates, L. G. Griffith, L. K. Landeen, A. Ratcliffe, Biomaterials 2002, 23, 4739.

[173] R. Landers, R. Mulhaupt, Macromol. Mater. Eng. 2000, $282,17$.

[174] R. Landers, A. Pfister, U. Hubner, H. John, R. Schmelzeisen, R. Mulhaupt, J. Mater. Sci.: Mater. Med. 2002, 37, 3107.

[175] T. H. Ang, F. S. A. Sultana, D. W. Hutmacher, Y. S. Wong, J. Y. H. Fuh, X. M. Mo, H. T. Loh, E. Burdet, S. H. Teoh, Mater. Sci. Eng. C 2002, 20, 35.

[176] R. Landers, U. Hubner, R. Schmelzeisen, R. Mulhaupt, Biomaterials 2002, 23, 4437.

[177] F. Fedchenko, "Stereolithography and other RP\&M Technologies", ASME Press, Dearborn 1996, p. 2.

[178] T. M. G. Chu, J. W. Halloran, S. J. Hollister, S. E. Feinberg, J. Mater. Sci.: Mater. Med. 2001, 12, 471.

[179] C. A. Heath, Trends Biotech. 2000, 18, 17.

[180] J. L. Platt, Crit. Rev. Immunol. 1996, 16, 331.

[181] H. M. Blau, T. R. Brazelton, J. M. Weimann, Cell 2001, 105, 829.

[182] M. R. Allison, R. Poulsom, S. Forbes, N. A. Wright, J. Pathol. 2002, 197, 419.

[183] S. L. Preston, M. R. Alison, S. J. Forbes, N. C. Direkze, R. Poulsom, N. A. Wright, J. Clin. Pathol.: Molec. Pathol. 2003, 56, 86 .

[184] S. C. Presnell, B. Petersen, M. Heidaran, Cell Dev. Biol. 2002, 13, 369 .

[185] A. Spraddling, D. DrummondBarbosa, T. Kai, Nature 2001, 414(6859), 98

[186] G. R. Martin, Proc. Natl. Acad. Sci. USA 1981, 78, 7634.

[187] M. J. Evans, M. H. Kaufman, Nature 1981, 292, 154.

[188] A. Bradley, M. Evans, M. H. Kaufman, E. Robertson, Nature 1984, 309, 255.

[189] P. A. Labosky, D. P. Barlow, B. L. M. Hogan, Development 1994, 120, 3197.

[190] K. H. Graves, R. W. Moreadith, Molecul. Reproduct. Dev. 1993, 36, 1993.

[191] J. A. Thomson, J. Kalishman, T. G. Golos, M. Durning, C. P. Harris, R. A. Becker, J. P. Hearn, Proc. Natl. Acad. Sci. USA 1995, 92, 7844.

[192] J. A. Thomson, J. Itskovitz, S. S. Shapiro, M. A. Waknitz, J. J. Swiergiel, V. S. Marshal, J. M. Jones, Science 1998 $282,1145$.

[193] B. E. Reubinoff, M. F. Pera, C. Y. Fong, A. Trounson, A. Bongso, Nature Biotechnol. 2000, 18, 399.

[194] A. M. Wobus, Molecul. Aspect. Med. 2001, 22, 149.

[195] A. E. Bishop, L. D. K. Buttery, J. M. Pollak, J. Pathol. 2002, 197, 424

[196] A. M. Wobus, K. M. Guan, Trends Cardiov. Med. 1998, 8, 64.

[197] M. V. Wiles, G. Keller, Development 1991, 111, 259.
[198] R. Wang, R. Clark, V. L. Bautch, Development 1992, 114, 303.

[199] J. Yamashita, H. Itoh, M. Hirashima, M. Ogawa, S. Nishikawa, T. Yurugi, M. Naito, K. Nakao, S. Nishikawa, Nature 2000, 408, 92.

[200] K. M. Guan, H. Chang, A. Rolletschek, A. M. Wobus, Cell Tissue Res. 2001, 305, 171.

[201] M. Schuldiner, R. Eiges, A. Eden, O. Yanuka, J. ItskovitzEldor, R. S. Goldstein, N. Benvenistry, Brain Res. 2001, 913, 201.

[202] J. Kramer, C. Hegert, K. M. Guan, A. M. Wobus, P. K. Muller, J. Rohwedel, Mechanisms Dev. 2000, 92, 193.

[203] N. Nakayama, D. Duryea, R. Manoukian, G. Chow, C. Y. E. Han, J. Cell Sci. 2003, 116, 2015.

[204] C. Dani, Cells Tissues Organs 1999, 165, 173.

[205] C. Dani, A. G. Smith, S. Dessolin, P. Letroy, L. Staccini, P. Villageois, C. Darimont, G. A. Ailhaud, J. Cell Sci. 1997, 110, 1279.

[206] T. Hamazaki, Y. Iiboshi, M. Oka, P. J. Papst, A. M. Meacham, L. I. Zon, N. Terada, FEBS Lett. 2001, 497, 15.

[207] D. H. Choi, H. J. Oh, U. J. Chang, S. K. Koo, J. X. Jiang, S. Y. Hwang, J. D. Lee, G. C. Yeoh, H. S. Shin, J. S. Lee, B. Oh, Cell Transplant. 2002, 11, 359.

[208] A. Shiroi, M. Yoshikawa, H. Yokota, H. Fukui, S. Ishizaka, K. Tatsumi, Y. Takahashi, Stem Cells 2002, 20, 284.

[209] L. D. K. Buttery, S. Bourne, J. D. Xynos, H. Wood, F. J. Hughes, S. P. F. Hughes, V. Episkopou, J. M. Pollak, Tissue Eng. 2001, 7, 89.

[210] M. F. Pittenger, A. M. Mackay, S. C. Beck, R. K. Jaiswal, R. Douglas, J. D. Mosca, M. A. Moorman, D. W. Simonetti, S. Craig, D. R. Marshak, Science 1999, 284, 143.

[211] K. Hanada, L. A. Solchaga, A. I. Caplan, T. M. Hearing, V. M. Goldberg, J. U. Yoo, B. Johnstone, J. Cell. Biochem. 2001, 81, 284.

[212] C. Perka, O. Shultz, R. S. Spizer, K. Lindenhayn, G. R. Burmester, M. Sittinger, Biomaterials 2000, 21, 1145 .

[213] J. T. Williams, S. S. Southerland, J. Souza, A. F. Calcut, R. G. Cartledge, Amer. Surg. 1999, 65, 22.

[214] P. A. Zulk, M. Zhu, H. Mizuno, J. Huang, J. W. Futrell, A. J. Katz, P. Benhaim, H. P. Lorenz, M. H. Hedrick, Tissue Eng. 2001, 7, 211.

[215] R. McKay, Science 1997, 276, 66.

[216] F. H. Gage, Science 2000, 287, 1433.

[217] J. G. Toma, M. Akhavan, K. J. L. Fernandes, F. BarnabeHeider, D. R. Kaplan, F. D. Miller, Nature Cell Biol. 2001, 3, 778 .

[218] C. R. R. Bjornson, R. L. Rietze, B. A. Reynolds, M. C. Magli, A. L. Vescovi, Science 1999, 283, 534.

[219] R. Galli, U. Borello, A. Gritti, C. Bjornson, M. Coleta, M. Mora, M. G. C. De Angelis, R. Fiocco, G. Cossu, A. L. Vescovi, Nature Neurosci. 2000, 3, 986.

[220] J. R. Sanchez-Ramos, J. Neurosc. Res. 2002, 69, 880.

[221] C. M. Verfaillie, Trends Cell Biol. 2002, 12, 502.

[222] K. V. Petrakova, A. A. Tolmacheva, A. J. Friedenstein, Bull. Exp. Biol. Med. 1963, 56, 87.

[223] A. J. Friedenstein, I. I. Piatetzk, K. V. Petrakova, J. Embryol. Exp. Morphol. 1966, 16, 381.

[224] A. J. Friedenstein, K. V. Petrakova, A. I. Kuroleso, G. P. Frolova, Transplantation 1968, 6, 230.

[225] A. J. Friedenstein, R. K. Chailakh, K. S. Lalykina, Cell Tissue Kinet. 1970, 3, 393.

[226] A. J. Friedenstein, U. F. Deriglasova, N. N. Kulagina, A. F. Panasuk, S. F. Rudakowa, E. A. Luria, I. A. Ruadkow, Exp. Hematol. 1974, 2, 83 . 
[227] A. I. Caplan, J. Orthop. Res. 1991, 9, 641.

[228] A. I. Caplan, Clin. Plast. Surg. 1994, 21, 1994.

[229] S. E. Haynesworth, J. Goshima, V. M. Goldberg, A. I. Caplan, Bone 1992, 13, 81.

[230] N. Jaiswal, S. E. Haynesworth, A. I. Caplan, S. P. Bruder, J. Cell. Biochem. 1997, 64, 295.

[231] S. K. Nilsson, M. S. Dooner, H. U. Weier, B. Frenkel, J. B. Lian, G. S. Stein, P. J. Quesenberry, J. Exp. Med. 1999, 189, 729.

[232] S. Kadiyala, R. G. Young, M. A. Thiede, S. P. Bruder, Cell Transplant. 1997, 6, 125.

[233] A. M. Mackay, S. C. Beck, J. M. Murphy, F. P. Barry, C. O. Chichester, M. F. Pittenger, Tissue Eng. 1998, 4, 415.

[234] B. Johnstone, T. M. Hering, A. I. Caplan, V. M. Goldberg, J. U. Yoo, Exp. Cell Res. 1998, 238, 265.

[235] H. A. Awad, D. L. Buttler, G. P. Boivin, F. N. L. Smith, P. Malaviya, B. Huibregtse, A. I. Caplan, Tissue Eng. 1999, 5, 267.

[236] R. G. Young, D. L. Butler, W. Weber, A. I. Caplan, S. L. Gordon, D. J. Fink, J. Orthop. Res. 1998, 16, 406.

[237] S. P. Bruder, N. Jaiswal, S. E. Hanesworth, J. Cell. Biochem. 1997, 64, 278.

[238] S. M. Devine, J. Cell Biochem. 2002, S38, 73.

[239] S. E. Haynesworth, M. A. Baber, A. I. Caplan, Bone 1992, $13,69$.

[240] S. P. Bruder, M. C. Horowitz, J. D. Mosca, S. E. Haynesworth, Bone 1997, 21, 225.

[241] S. P. Bruder, N. S. Ricalton, R. E. Boynton, T. J. Connolly, N. Jaiswal, J. Zala, F. P. Barry, J. Bone Miner. Res. 1998, 13, 655.

[242] F. Barry, R. Boynton, M. Murphy, J. Zaia, Biochem. Biophys. Res. Commun. 2001, 289, 519.

[243] J. Ringe, C. Kaps, G. R. Burmester, M. Sittinger, Naturwissenschaften 2002, 89, 338.

[244] D. Baksh, J. E. Davies, P. W. Zandstra, Exp. Hematol. 2003, 31, 723 .

[245] K. Inoue, H. Ogushi, T. Yoshikawa, M. Okumura, T. Sempuku, S. Tamai, Y. Dohi, J. Bone Miner. Res. 1997, 12, 989.

[246] G. D’Ippolito, P. C. Schiller, C. Ricordi, B. A. Roos, G. A. Howard, J. Bone Miner. Res. 1999, 14, 115.

[247] S. C. Mendes, J. M. Tibbe, M. Veenhof, K. Baker, S. Both, P. P. Platenburg, F. C. Oner, J. D. de Bruijn, C. A. van Blitterswijk, Tissue Eng. 2002, 8, 911.

[248] M. F. Pittenger, Nature 2001, 414, 132.

[249] J. A. Jadlowiec, A. B. Celil, J. O. Hollinger, Expert. Opin. Biol. Ther. 2003, 3, 409.

[250] S. D. Bodden, Clin. Orthop. 1999, 367S, S84.

[251] M. Lind, C. Bumger, Eur. Spine J. 2001, 10, S102.

[252] S. T. Yoon, S. D. Boden, Clin. Orthop. 2002, 395, 33.

[253] P. B. Malafaya, G. A. Silva, E. T. Baran, R. L. Reis, Curr. Opin. Solid State Mater. Sci. 2002, 6, 283.

[254] M. R. Urist, Science 1965, 150, 893.

[255] M. R. Urist, Science 1983, 220, 680.

[256] M. R. Urist, A. G. Brownwll, W. M. Hohl, J. Buyske, A. Lietze, P. Tempst, M. Hunkapiller, R. G. Delange, Proc. Natl. Acad. Sci. USA 1984, 81, 371.

[257] S. Gallea, F. Lallemand, A. Atfi, G. Rawadi, V. Ramez, S. SpinellaJaegle, S. Kawai, C. Faucheau, L. Huet, R. Baron, S. Roman-Roman, Bone 2001, 28, 491.

[258] S. D. Cook, Orthopedics 1999, 22, 669.

[259] S. P. Bruder, B. S. Fox, Clin. Orthop. 1999, 367S, S68.

[260] R. Govinden, K. D. Bhoola, Pharmacol. Ther. 2003, 98, 257.
[261] M. Lind, B. Shumacker, K. Soballe, J. Keller, F. Melsen, C. Bunger, Acta Orthop. Scand. 1993, 64, 553.

[262] E. Canalis, D. Agnusdei, Calcif. Tissue Int. 1996, 58, 133.

[263] S. Y. Rabbany, B. Heissig, K. Hattori, S. Rafii, Trends Mol. Med. 2003, 9, 109.

[264] S. Uchida, A. Sakai, H. Kudo, H. Otomo, M. Watannuki, M. Tanaka, M. Nagashima, T. Nakamura, Bone 2003, 32, 491.

[265] T. Furumatsu, Z. N. Shen, A. Kawai, K. Nishida, H. Manabe, T. Oohashi, H. Inoue, Y. Ninomiya, J. Biochem. 2003, 133, 633.

[266] R. T. Franceschi, G. Xiao, J. Cell. Biochem. 2003, 88, 446.

[267] L. Rasubala, H. Yoshikawa, K. Nagata, T. Ijima, M. Ohishi, Br. J. Oral Maxillofac. Surg. 2003, 41, 173.

[268] G. N. Bancroft, V. I. Sikavitsas, J. van den Dolder, T. L. Sheffield, C. G. Ambrose, J. A. Jansen, A. G. Mikos, Proc. Natl. Acad. Sci. USA 2002, 99, 12600.

[269] V. I. Sikavitsas, G. N. Bancroft, A. G. Mikos, J. Biomed. Mater. Res. 2002, 62, 136.

[270] E. T. Botchwey, S. R. Pollack, E. M. Levine, C. T. Laurencin, J. Biomed. Mater. Res. 2001, 55, 242.

[271] Q. Q. Qiu, P. Ducheyne, P. S. Ayyaswamy, In Vitro Cell Dev. Biol. 2001, 37, 157.

[272] P. M. Droppert, J. Br. Interplant. Soc. 1990, 43, 19.

[273] R. K. Sinha, S. A. Shah, E. L. Hume, R. S. Tuan, Spine J. 2002, 2, 239.

[274] M. E. Gomes, V. I. Sikavitsas, E. Behravesh, R. L. Reis, A. G. Mikos, J. Biomed. Mater. Res. 2003, 67A, 87.

[275] S. A. Goldstein, Ann. N.Y. Acad. Sci. 2002, 961, 183.

[276] A. E. Thomas, Clin. Orthop. 1999, 367S, S59.

[277] Y. H. An, R. J. Friedman, "Animal Models in Orthopaedic Research", $1^{\text {st }}$ edition, CRC Press, Boca Raton, FL 1999, p. 241.

[278] J. M. Orban, K. G. Marra, J. O. Hollinger, Tissue Eng. 2002, 8, 529.

[279] S. Kadyala, N. Jaiswal, S. P. Bruder, Tissue Eng. 1997, 3, 173.

[280] S. P. Bruder, K. H. Kraus, V. M. Goldberg, S. Kadiyala, J. Bone Joint Surg. Am. 1998, 80, 985.

[281] S. C. Mendes, J. Bezemer, M. B. Classe, D. W. Grypma, G. Bellia, F. D. Innocenti, R. L. Reis, C. A van Blitterswijk, J. D. de Bruijn, Tissue Eng., 2003, 9, S91.

[282] C. E. Holy, J. A. Fialkov, J. E. Davies, M. S. Shoichet, J. Biomed. Mater. Res. 2003, 65A, 447.

[283] D. Gazit, G. Turgeman, P. Kelley, E. Wang, M. Jalenak, Y. Zilberman, I. Moutsatos, J. Gene Med. 1999, $1,121$.

[284] J. Y. Lee, D. Musgrave, D. Pelinkovic, D. Fukushima, J. Cummins, A. Usas, P. Robbins, J. Huard, J. Bone Joint Surg. Am. 2001, 83, 1032.

[285] K. Partdrige, X. Yang, N. M. Clarke, Y. Okubo, K. Bessho, W. Sebald, S. M. Howdle, K. M. Shakesheff, R. O. Oreffo, Biochem. Biophys. Res. Commun. 2002, 292, 144.

[286] P. B. Malafaya, G. A. Silva, E. T. Baran, R. L. Reis, Curr. Opin. Solid State Mater. Sci. 2002, 6, 297.

[287] L. D. Shea, E. Smiley, J. Bonadio, D. J. Mooney, Nature Biotechnol. 1999, 17, 551.

[288] J. Bonadio, E. Simley, P. Patil, S. Goldstein, Nature Med. 1999, 5, 753.

[289] J. A. Burdick, K. S. Anseth, Biomaterials 2002, 23, 4315.

[290] J. A. Burdick, M. N. Mason, A. D. Hinman, K. Thorne, K. S. Anseth, J. Controlled Release 2002, 83, 53. 
[291] K. Whang, D. C. Tsai, E. K. Nam, M. Aitken, S. M. Sprague, P. K. Patel, K. E. Healy, J. Biomed. Mater. Res. 1998, 42, 491.

[292] W. L. Murphy, M. C. Peters, D. H. Kohn, D. J. Mooney, Biomaterials 2000, 21, 2521.

[293] S. Kokubo, R. Fujimoto, S. Yokota, S. Fukushima, K. Nozaki, K. Takahashi, K. Miyata, Biomaterials 2003, 24, 1643.

[294] L. L. Hench, J. M. Polak, Science 2002, 295, 1014.

[295] M. P. Lutolf, F. E. Weber, H. G. Schmoekel, J. C. Schense, T. Kohler, R. Muller, J. A. Hubbell, Nat. Biotech. 2003, 21, 513.

[296] M. P. Lutolf, J. L. LauerFields, H. G. Schmoekel, A. T. Metters, F. E. Weber, G. B. Fields, J. A. Hubbell, Proc. Natl. Acad. Ssi. USA 2003, 100, 5413.

[297] T. C. Holmes, Trends Biotechnol. 2002, 20, 16.

[298] J. D. Hartgerink, E. Beniash, S. I. Stupp, Science 2001, 294, 1684

[299] J. D. Hartgerink, E. Beniash, S. I. Stupp, Proc. Natl. Acad. Ssi. USA 2002, 99, 5133.
[300] G. A. Silva, C. Czeisler, K. L. Niece, E. Beniash, D. Harrington, J. A. Kessler, S. I. Stupp, Science 2004, 303, 1352.

[301] A. L. Oliveira, C. M. Alves, R. L. Reis, J. Mater. Sci.: Mater. Med. 2002, 12, 1181.

[302] A. L. Oliveira, P. B. Malafaya, R. L. Reis, Biomaterials 2003, 24, 2575.

[303] I. B. Leonor, R. L. Reis, J. Mater. Sci.: Mater. Med. 2003, $14,435$.

[304] Y. Zhang, Z. Zhang, J. Biomed. Mater. Res. 2001, 61, 1.

[305] P. J. ter Brugge, J. C. G. Wolk, J. A. Jansen, J. Biomed. Mater. Res. 2002, 60, 70.

[306] J. E. G. Hulshoff, K. van Dijk, J. E. de Ruijter, F. J. R. Rietveld, L. A. Ginsel, J. A. Jansen, J. Biomed. Mater. Res. 1998, 40, 464.

[307] Y.-L. Chang, C. M. Standford, J. S. Wefel, J. C. Keller, Int. J. Oral Maxillofac. Impl. 1999, 14, 239.

[308] A. J. Salgado, J. E. Figueiredo, O. P. Coutinho, R. L. Reis, J. Mater. Sci.: Mater. Med., in press. 